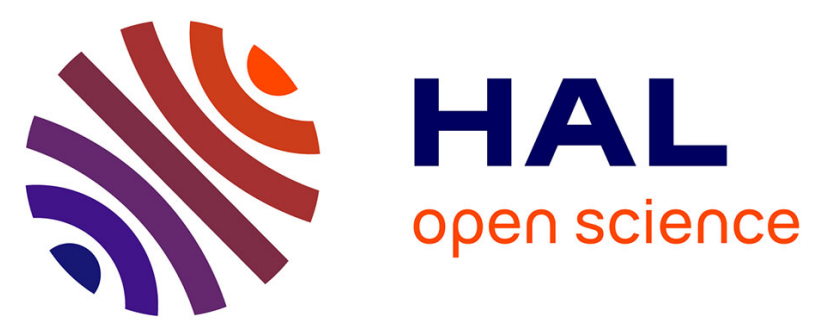

\title{
Modelling of impact of presence/absence of suspended particulate organic matter from river and sea and effluent wastewater on fluorescence signal in the coastal area of Gapeau River
}

\author{
Ibrahim El-Nahhal, Roland Redon, Michel Raynaud, Yasser El-Nahhal, \\ Stéphane Mounier
}

\section{To cite this version:}

Ibrahim El-Nahhal, Roland Redon, Michel Raynaud, Yasser El-Nahhal, Stéphane Mounier. Modelling of impact of presence/absence of suspended particulate organic matter from river and sea and effluent wastewater on fluorescence signal in the coastal area of Gapeau River. Environmental Science and Pollution Research, inPress, 10.1007/s11356-021-13265-2 . hal-03171038

\author{
HAL Id: hal-03171038 \\ https://hal.science/hal-03171038
}

Submitted on 16 Mar 2021

HAL is a multi-disciplinary open access archive for the deposit and dissemination of scientific research documents, whether they are published or not. The documents may come from teaching and research institutions in France or abroad, or from public or private research centers.
L'archive ouverte pluridisciplinaire HAL, est destinée au dépôt et à la diffusion de documents scientifiques de niveau recherche, publiés ou non, émanant des établissements d'enseignement et de recherche français ou étrangers, des laboratoires publics ou privés. 
1 Manuscript prepared for possible publication in ESPR 04-12-2020

7 Modelling of impact of presence/absence of suspended particulate organic matter from river and sea and efflu8 ent wastewater on fluorescence signal in the coastal area of Gapeau River

15 Ibrahim EL-Nahhal ${ }^{2}$, Roland Redon ${ }^{\mathrm{a}}$, Michel Raynaud ${ }^{\mathrm{a}}$, Yasser EL-Nahhal ${ }^{\mathrm{b}}$, Stéphane Mounier ${ }^{\mathrm{a}}$

16 aniversité de Toulon, Aix Marseille Univ, CNRS, IRD, MIO - CS 60584, 83041 TOULON CEDEX 9, France

17 bepartment of Environmental and Earth Sciences, Faculty of Science, The Islamic University-Gaza,P.O Box 108, 1800970 Palestinian Territories.

19 “Corresponding author: elnahhal.i@gmail.com (Ibrahim Y. Z. EL-Nahhal)

20 "Corresponding author ORCID: https://orcid.org/0000-0002-3321-7359 
21 Abstract:

22 Organic matter has an important role in biogeochemistry in aquatic environments. This study investigated impact of 23 suspended particulate organic matter (SPOM) on fluorescence signal of mixtures of three water types (River water 24 RW, Sea water SW, effluent wastewater WW) using three-dimensional excitation emission fluorescence spectroscopy 25 (3D-EEMs) and Parallel factor analysis PARAFAC and multilinear regression. Four irradiation experiments (Exp.1, 26 Exp.2, Exp.3 and Exp.4) were conducted during different times of year ( two in autumn, one in winter and one in 27 spring season). Samples were exposed to natural sunlight on laboratory rooftop in University of Toulon, France, with 28 another set of samples were kept in dark as control samples. Three components $(\mathrm{C} 1, \mathrm{C} 2, \mathrm{C} 3)$ model was validated by 29 split-half and Concordia from the whole EEM dataset of all irradiation experiments. No protein-like fluorophores or 30 PARAFAC components was found. The study revealed the effect of SPOM presence/absence on fluorescence signal 31 of DOM and on resulting parameters of multilinear regression MLR model and kinetic constant of these MLR param32 eters. Kinetic constant (k) for all MLR coefficients was in order of greatness as Exp.1 (SPOM of WW only in mixtures 33 ) > Exp.3 (SPOM of SW only in mixtures ) > Exp.2 (SPOM of RW only in mixtures )> Exp.4 (All SPOM of RW, SW, $34 \mathrm{WW}$ in mixtures ) indicating that SPOM of WW is the most resistant to photodegradation. For dark control samples, 35 only relative standard deviation RSD could be calculated from dataset. RSD values for C3 were the highest indicating 36 its chaotic variations and the lowest RSD values were found for both C1 and C2 for all experiments. Statistical differ37 ences has been found between control and irradiated experiments. These models developed in this study can be used 38 to predict fluorescence signal of anthropogenic effluent DOM during its transport in river systems to coastal zone.

\section{Keywords:}

40 Suspended Particulate Organic matter SPOM, Fluorescence Spectroscopy, parallel factor analysis PARAFAC model41 ing, Solar Irradiation, mixing experiments. 


\section{Introduction}

43 Organic matter in natural waters can be operationally classified and divided into dissolved organic matter (DOM) or 44 suspended particulate organic matter (SPOM) depending on the filtration and filter size (Osburn et al., 2012; Gagné and Tremblay 2009). DOM pool consists of a wide range of organic molecules originating from decaying dead stuff (plants and animals). Such organic molecules could be humic substances (i.e. humic and fulvic acid)or non-humic substances such as proteins, and carbohydrates with varying molecular size and functional groups (Her et al.2003). Whereas, SPOM pool may consist of living microorganisms (e.g. bacteria and viruses), organic/inorganic particles organic polymers among others (Chin et al.1998; Leppard et al. 2011). SPOM in water plays an important role in characterizing the fate of (DOM) in ecosystems. SPOM and DOM are an important constituent in aquatic environments and plays a significant role in the transport, stability and bioavailability of several organic/inorganic pollutants that results from anthropogenic activity (e.g. heavy metals, pesticides and polycyclic aromatic hydrocarbons) (Akkanen et al. 2004; Hirose 2007; Baker et al. 2008; Ishii and Boyer 2012). However, DOM in aquatic ecosystems is considered to be the most important and significant fraction of organic matter due to its involvement in so many environmental processes (Søndergaard and Thomas, 2004)

In addition, both of them have a role in global biogeochemical cycling of carbon and nutrients. It is critical for the better understanding of carbon cycle to differentiate sources of DOM in aquatic environment and the factors which play important roles in its sources and sinks like biodegradation and photodegradation (McCallister et al. 2006a,b; Dalzell et al. 2009). More research attention has been given to study the role in environmental photochemistry of DOM than that of SPOM (Mopper et al. 2014). Solar irradiation of (SPOM) may result in production of dissolved nutrients and/or DOM in considerable amounts which may enrich the aquatic system. For instance, previous studies (Liu and Shank 2015; Mayer et al. 2006; Riggsbee et al. 2008; Southwell et al. 2010; Estapa and Mayer 2010; Pisani et al. 2011) investigated the influence of sunlight on POM and found that it undergo similar photochemical reactions as DOM due to absorbance of UV-VIS light which are the same wavelengths that DOM can absorb. Moreover, He et al. (2016) evaluated the effect of SPOM in attenuating the fraction of dissolved organic carbon and revealed that SPOM can reduce the concentration of dissolved organic carbon in water systems through adsorption process. Moreover, influence of SPOM in fluorometry of DOM were investigated by several authors (e.g. Laane and Kramer 1990; De Souza Sierra and Donard 1991; Baker and Spencer 2004; Boyd and Osburn 2004; Callahan et al. 2004; Kowalczuk et al. 2003, 2005; Murphy et al. 2008). Evolution of fluorophores of DOM (i.e. FDOM) is being followed using spectrofluorometry which is a qualitative and semi-quantitative technique. Spectrofluorometry technique of three-dimensional excitation-emission matrix (EEM) spectroscopy has several advantages for the detection of fluorophores of DOM in 
aquatic environment because it is fast and non-destructive with no need for sample pre-treatment and is highly sensitive

73 for detection of even-low concentrations of samples which is the case in several aquatic environments. In addition to

74 the fact that type and origin of samples (riverine, marine, wetlands) can be figured out and types and relative concentrations of fluorophores constituting DOM can also be known using three-dimensional excitation-emission matrix (EEM) spectroscopy.

Previous studies (He et al. 2016) investigated the influence of SPOM in light scattering, adsorption of DOM, attenuation of dissolved organic carbon and other matters, however the impact of presence/absence of SPOM on fluorescence signal of naturally occurring mixtures is not fully understood. Accordingly, this study was designed to bridge the gap of knowledge in the field of SPOM effect on fluorescence signal of naturally occurring mixtures of river water and effluent wastewater and sea water. Therefore, the research question of this study is that will the presence/absence of particulate matter from one of three water types (river water, seawater, effluent wastewater) affect the modelling and kinetics of degradation of fluorescence signal of different mixtures of these water types after solar irradiation . So far, the objectives of this study are to investigate the effect of presence/absence of SPOM on fluorescence signal of naturally occurring mixtures through mixing experiments and to examine the impact of solar photodegradation on mixtures of different types of water (i.e. river water RW, Sea water SW and wastewater effluent WW) by using the technique of three-dimensional fluorescence spectroscopy and parallel factor analysis PARAFAC by developing a multilinear regression model for tracking the effect of SPOM on fluorescence signal of the above mentioned mixtures to simulate naturally occurring mixing in coastal zone which could be used in further work to develop online or real-time remotesensing monitoring software.

\section{$91 \quad$ Material and methods}

\section{Study area and Sample Collection}

93 Gapeau river, a small coastal river, is situated in Var department in Provence-Alpes-Côte d'Azur region located in

94 Southeastern France and is the second largest river in Var department. It discharges its runoff in Mediterranean Sea at 95 Hyeres City. It is submitted to various anthropogenic inputs especially thirteen wastewater treatment plants in its water 96 catchment. In this study, the focus was on anthropogenic organic matter from La Crau wastewater treatment plant 97 WWTP which served 50,086 inhabitants. This WWTP uses secondary and tertiary technologies for wastewater 98 treatment such as activated sludge technology, sand filter, prolonged aeration and anaerobic sludge digestion. 99 Sampling was done using plastic bottles of one liter each to sample 1 liter of River water, wastewater treatment plant 100 effluent and Sea water. Exact GPS locations of these sampling sites are the same according to recent procedures (EL101 Nahhal et al. 2020). Eight sampling cruises were conducted for solar irradiation experiments, sampling dates 


\section{Collected Samples Filtration}

104 Having three types of water (River water RW, Sea water SW and wastewater effluent WW) and making permutations of filtering of two types of water and leaving the last one non-filtered, we end up with experiments described in Table 2. Filtration process (Removal of SPOM) was conducted using a filtration kit and MilliPore filters (Type GNWP 0.20 $\mu \mathrm{m}, 47 \mathrm{~mm}$ diameter) to filter (one litter) $1 \mathrm{~L}$ of RW and 1L SW and leaving $1 \mathrm{~L}$ of WW not filtered (Exp. 1 in table 2) to investigate the impact of SPOM from this non-filtered WW on mixtures (prepared according to the next section in Materials and methods). Experiment Exp.2 indicates that 1L of RW was not filtered and the other two 1L of SW and $1 \mathrm{~L}$ of WW were filtered to study the impact of these SPOM coming from river water RW on mixtures (the following

\section{Preparing water mixtures}

113 Vials of quartz were used because quartz allows absorption of UV-VIS energy. Different mixing percentages taken 114 from the collected 1L RW, IL SW and 1L WW (filtered or not filtered as explained in the previous section) were taken 115 by pipette and inserted in quartz vial according to table 1 (or Fig.1). These mixing percentages are speculated to 116 represent actual mixing in nature. After having the required mixing percentages, all quartz vials were hand-shaken to 117 have representative mixtures. Another fifteen control samples had the same mixing percentages and prepared in dark 118 vials. Each intersection point and summits in the ternary diagram in Fig.1 represents a corresponding quartz vial that contains the indicated percentages in the ternary diagram of mixtures. Exact volume of RW, SW and WW in each quartz vial is indicated in Table 1 . Total volume of each quartz vial is $50 \mathrm{~mL}$.

122 Shimadzu TOC-5000A Total Organic Carbon Analyzer (catalytic combustion) with module ASI-5000A has been used to measure dissolved organic carbon (DOC) at high temperature $\left(720^{\circ} \mathrm{C}\right)$ and with module SSM-5000A to measure

124 particulate organic carbon (POC). Acidification was performed to $\mathrm{pH}<2$ using $2 \mathrm{~N} \mathrm{HCl}$ on samples of $1 \mathrm{~L} \mathrm{RW}, 1 \mathrm{~L}$ $\mathrm{SW}$ and $1 \mathrm{~L} \mathrm{WW}$ in each irradiation experiment and $\mathrm{CO}_{2}$ was removed by purging samples with oxygen. UV-visible absorption spectra (between 250-800 nm) were measured using a PerkinElmer Lambda 10500 UV/VIS spectrophotometer with a $1 \mathrm{~cm}$ quartz cuvette with the blank as MilliQ water for the series of dilutions $(100 \%, 50 \%, 25 \%, 12,5 \%)$ of 1L RW, 1L WW, 1LSW to check for inner filter effect according to Tucker et al. (1992).

130 Four irradiation experiments were conducted at different time of year (Table 2). The first two experiment were 
132 in (Table 2). Fifteen mixtures in quartz vials (according to previous section ) were prepared and transferred on rooftop

133 of our laboratory MIO at Campus La Garde, Universite de Toulon in plank at sufficient distances from each other to

134 have the same irradiation conditions as shown in Fig.2. The used apparatus for these experiments is shown in Fig.2.

135 Another fifteen control samples were prepared and incubated in dark box in vicinity of irradiated samples.

136 Measurements of light intensity.

137 Météo-France (www.meteofrance.com) provided solar irradiance (light intensity) measured in milliVolts mV for each

138 day of irradiation as mentioned in table 2 and the cumulative light intensity was calculated and graphed for each 139 irradiation experiment.

\section{Excitation Emission Matrix EEM fluorescence spectroscopy}

141 Spectrofluorometric measurements were completed using a 1-cm quartz cuvette with a Hitachi F-4500 spectrofluo142 rometer with PMT voltage of $700 \mathrm{~V}$, at $25^{\circ} \mathrm{C}$ and sampling using a pipette a $3 \mathrm{~mL}$ from each irradiated quartz vial. A 143 correction for the change in volume was done by replacing the taken $3 \mathrm{~mL}$ aliquots by another $3 \mathrm{~mL}$ of deionized water 144 therefore steady state concentration was kept till the end of each irradiation experiment. Sodium azide $(100 \mu \mathrm{L}$ of $1 \mathrm{M}$ $145 \mathrm{NaN} 3$ ) was added for each sampled $3 \mathrm{~mL}$ to inhibit biodegradation during EEM fluorescence measurements. Addition 146 of sodium azide NaN3 has no effect on fluorescence intensity in EEMs as revealed by Patel-Sorrentino et al. (2002). 147 Excitation wavelengths (Ex) spectra were measured from 200 to $400 \mathrm{~nm}$ at $5 \mathrm{~nm}$-increment, and emission wavelengths 148 (Em) spectra from 220 to $420 \mathrm{~nm}$ at $5 \mathrm{~nm}$-intervals with scan speed set at 2,400 nm.min-1. Slit width of $5 \mathrm{~nm}$ was set 149 for both excitation and emission wavelengths. EEM datasets of solar irradiation experiments were processed using 150 Matlab 2013a (Math Works Inc., USA). All recorded EEMs were blank-corrected through the subtraction of EEMs of 151 Sealed ultrapure Perkin Elmer deionized water cell. Integrated Raman signal of Sealed ultrapure Perkin Elmer deion152 ized water cell was used to normalize values of each excitation-emission matrix and it was calculated by integrating 153 the area under the curve from 370 to $420 \mathrm{~nm}$ (Lawaetz and Stedmon 2009). All fluorescence intensity were in Raman 154 units (RU) . Only EEMs before irradiation of Samples No. 1,2 and 3 in table 1 are presented in the results and discussion section whereas the remaining EEMs are not shown since the total number of EEMS for all four irradiation experiments is 648 EEMs.

\section{Parallel factor analysis (PARAFAC) of EEM data}

158 PARAFAC is a powerful multiway technique used to decompose and fully make use of the EEM dataset. The principle of PARAFAC is that it decomposes any given EEM dataset into its underlying EEM spectra constituents (Murphy et al. 2013) which are a set of trilinear terms and a residual array using an alternating least squares algorithm to minimize sum of squared residuals in a trilinear model. Resulting PARAFAC components represents fluorophores having similar 
162 fluorescing properties which constitute the EEM dataset. PARAFAC modeling was performed on the whole EEM

163 datasets of all irradiation experiments (Table 2) using MATLAB software (MathWorks R2015b, USA) and NWAY

164 toolbox and DOMFluor toolbox (http://www.models.life.ku.dk) (Micó et al. 2019; Stedmon and Bro 2008) for a total

165 of 648 EEMs. Numerical filter was taken as $25 \mathrm{~nm}$ to eliminate Raman and Rayleigh scattering according to Zepp

166 method (Zepp et al. 2004). Based on CONCORDIA score, split- half analysis and visual inspection of spectral shapes

167 of each PARAFAC component, the accepted number of PARAFAC components was determined (Bro 1998). Split-

168 half analysis were performed for validation of PARAFAC model results (Stedmon et al. 2003; Murphy et al. 2013).

169 Scores of each PARAFAC component represent relative concentration of each PARAFAC component in EEM dataset.

170 Quantitative and qualitative variations of the composition of organic matter can be extracted from PARAFAC modelling of EEM datasets. Normalization of contributions of PARAFAC components was performed by dividing each contribution with its corresponding daily maximum contribution.

173 Multilinear regression between scores of PARAFAC components and $f_{R W}$ and $f_{S W}$

174 Based on the explanation recently described (EL-Nahhal et al. 2020), the final multilinear regression equation as a 175 function of $f_{R W}$ and $f_{S W}$ is:

$$
\mathrm{C}^{*}{ }_{\mathrm{i}}=\mathrm{A}^{\mathrm{Ww}} \mathrm{i}_{\mathrm{i}, 0}+\mathrm{A}^{\mathrm{Ww}} \mathrm{i}_{\mathrm{i}, 1} \cdot f_{S W}+\mathrm{A}^{\mathrm{Ww}} \mathrm{i}_{\mathrm{i}, 2} \cdot f_{R W}
$$

176 Where $f_{R W}$ and $f_{S W}$ are percentages in mixture in a given quartz vial of RW and $\mathrm{SW}$ as described in Fig.1;

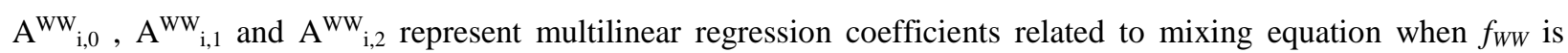
expressed in terms of percentages $\left(f_{R W}\right.$ and $\left.f_{S W}\right)$. $\mathrm{i}$ is the number of a given PARAFAC component (e.g. C1, C2, C3) . More details and explanations are thoroughly given elsewhere (EL-Nahhal et al. 2020).

180 Kinetics of Multilinear regression parameters $A^{w w_{i, 0}}, A^{w w_{i, 1}}$ and $A^{w w_{i, 2}}$

$181 \mathrm{~A}^{\mathrm{Ww}_{\mathrm{i}, 0}}, \mathrm{~A}^{\mathrm{Ww}} \mathrm{i,1}$ and $\mathrm{A}^{\mathrm{Ww}} \mathrm{i,2}$ values change for each day of irradiation in a given experiment. Changes in their values 182 were modelized to rate order kinetic equation in order to get a model for the evolution of fluorescence signal as a 183 function of irradiation energy expressed in volts $\mathrm{V}$; with their kinetic formulas expressed as $\mathrm{A}^{\mathrm{Ww}} \mathrm{i}_{0}(\mathrm{~V}), \mathrm{A}^{\mathrm{Ww}} \mathrm{i}_{1,1}(\mathrm{~V})$ 184 and $\mathrm{A}^{\mathrm{Ww}} \mathrm{i}_{2}(\mathrm{~V})$.

185 Accordingly, multilinear regression model in eq. 1 can be expressed kinetically as follow:

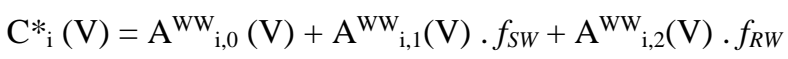


Multi-regression analysis was used to investigate the strength of linear relationships between concentration scores of fluorescent components obtained from PARAFAC analysis and water mixing composition. Regression and correlation analyses and relative standard deviation for multilinear regression parameters in control non-irradiated samples were performed using Microsoft Excel 2016. Significances of correlations in the statistics were evaluated.

\section{$191 \quad$ Results and Discussions}

192 Measured light intensity in mV for Exp.1, Exp.2, Exp.3 and Exp.4 are presented in Fig.3. It can be noticed from Fig.3 that light intensity in Exp.1 which was conducted in autumn and the third one Exp.3 which was conducted in winter season have the lowest light intensity compared to Exp.2 (conducted in autumn) and Exp.4 (conducted in spring). The high light intensity in autumn Exp.2 in December 2015 compared to autumn Exp.1 in November 2015 is due to unpredictable weather in PACA (Provence Alpes Cote d'Azur) region in southeastern France. This explains the rapid photodegradation in Exp.2 and Exp.4.

\section{UV-VIS Absorption spectra of 1L RW, 1L WW, 1L SW}

UV-VIS absorption spectra of sampled 1-liter river water RW, 1-liter effluent wastewater WW and 1-liter seawater and the dilution series $100 \%, 50 \%, 25 \%$ and 12,5\% for each water type are shown in Fig. 4. It can be seen from Fig 4 that UV-VIS absorption spectrum of all water types RW, WW and SW decrease linearly with dilution series (100\%, $50 \%, 25 \%$ and $12,5 \%$ ) showing no primary or secondary inner filter effect in these waters (RW,WW \& SW) as previously described (Tucker et al. 1992; Ohno 2002). In addition, sand filter; a tertiary wastewater treatment technology; is used in the WWTP of La Crau city in this study removes inner filter effect caused by SPOM and this is in accordance with Sgroi et al. (2020) who found no inner filter effect for effluent tertiary wastewater after sand filtration.

\section{Excitation Emission Matrix of Example Samples 1,2 and 3 before irradiation and after irradiation}

Collected water samples (RW, SW and WW) have different origin to match the naturally occurring mixtures. Filtration of samples was done to match naturally occurring precipitation in ecosystems. For instance, at rough sea water movement, SPOM are at most whereas, at soft sea, SPOM tend to precipitate resulting in as clean solution as filtrated

\section{4 the effect of solar irradiation (the remaining EEMs for each sample in table 1 are not shown).}

\section{First experiment Exp.1 (in autumn) .}

216 First irradiation experiment (Exp. 1) was conducted in the autumn season starting irradiation from November 10 to 
217 November 202015 (Table 2). EEMs of Samples no 1, 2 and 3 in table 1 (before irradiation and after irradiation and

218 the difference between before and after irradiation) are presented in Fig.5 for Exp.1 in which SPOM from effluent

219 WW is present whereas SPOM from RW and SW were absent. Concentrations of POC of WW was $3 \pm 0.23 \mathrm{mg} / \mathrm{l}$ 220 whereas DOC concentration of RW and SW were $2.1 \pm 0.18 \mathrm{mg} / \mathrm{l}$ and $2.4 \pm 0.19 \mathrm{mg} / \mathrm{l}$. It can be seen in Fig. 5 that 221 unfiltered and unmixed effluent WW (sample no. 3) contains the highest fluorescence intensities before irradiation and after irradiation compared to samples no. 1 and 2. All fluorescence peaks got photodegraded as shown by the diminution of fluorescence intensity of them as clearly can be seen in color bar values.

Second experiment Exp. 2 (in autumn)

Second irradiation experiment (Exp. 2) was also conducted in autumn season starting irradiation from December 20 until December 172015 (Table 2). EEMs of Samples no 1, 2 and 3 in table (before irradiation and after irradiation and the difference between before and after irradiation) are presented in Fig.6 for Exp. 2 in which particulate organic matter from river water is present whereas seawater and effluent wastewater were filtered. The concentration of POC of RW was $0.5 \pm 0.14 \mathrm{mg} / \mathrm{l}$ whereas DOC concentration of SW and WW were $2 \pm 0.3 \mathrm{mg} / \mathrm{l}$ and $3.5 \pm 0.2 \mathrm{mg} / \mathrm{l}$. It can be seen in Fig.6 that peak $\mathrm{C}$ representing humic-like fluorophores and peak M representing marine humic-like fluorophores (Coble 1996) has medium intensity in sample no. 1 (unmixed RW i.e. 100\% RW) and higher intensity peak C in the sample no. 2 (unmixed SW i.e. 100\% SW) and the highest intensity found in sample no.3 (unmixed WW). In addition, peaks $\mathrm{B}$ and $\mathrm{T}$ which represent protein-like fluorophores (tyrosine-like and tryptophan-like) are also higher in fluorescence intensity compared to samples no. 1 and 2 before irradiation. After irradiation, fluorescence intensity of peak B (tyrosine-like fluorophores) and peak T (Tryptophan-like fluorophores) degraded as shown with their lowest fluorescence intensities shown as the values in the color bar. Furthermore, the light intensity in the second experiment in autumn is less than the light intensity in experiment Exp.1. This suggest slower photochemical degradation.

Third experiment Exp. 3 (in winter season)

239 Third irradiation experiment (Exp. 3) was conducted in the winter season starting irradiation from February 15 until

240 March 42016 (Table 2). EEMs of Samples no 1, 2 and 3 in table (before irradiation and after irradiation and the 241 difference between before and after irradiation) are presented in Fig.7 for Exp. 3 in which particulate organic matter 242 from sea water is present whereas river water and effluent wastewater were filtered. The concentration of POC of SW 243 was $0.6 \pm 0.07 \mathrm{mg} / \mathrm{l}$ whereas DOC concentration of RW and WW were $2 \pm 0.18 \mathrm{mg} / \mathrm{l}$ and $3.7 \pm 0.14 \mathrm{mg} / 1$. It can be seen 244 in Fig.7 that sample no 2 ( unmixed and unfiltered SW) has the lowest fluorescence intensity for most peaks (C, A, M, 245 B, and T) before irradiation and sustained more or less the same fluorescence intensity after irradiation. There was no 246 inner-filter effect in this sample as checked by UV-VIS absorption spectra of SW as explained above. For filtered WW 247 (sample no. 3), it is characterized by the highest fluorescence intensities (before irradiation and after irradiation) 
compared to samples no 1 and 2. Moreover, peaks C and M degraded the most which is in agreement with Zhu et al.

249 (2017b) who found that CDOM from terrestrial origins was more susceptible to photochemical degradation compared

250 to CDOM from biological sources.

251 Fourth experiment Exp.4 (in spring season)

252 Last irradiation experiment (Exp. 4) was conducted in spring season starting irradiation from May 05 until May 27

2532016 (Table 2). EEMs of Samples no 1, 2 and 3 in table (before irradiation and after irradiation and the difference

254 between before and after irradiation) are presented in Fig.8 for Exp.4 in which particulate organic matter from RW,

255 SW and WW are present at the same time in all the samples of Table 1. Concentrations of POC of RW, SW and WW were $0.6 \pm 0.1 \mathrm{mg} / 1,0.7 \pm 0.2 \mathrm{mg} / \mathrm{l}$ and $2.75 \pm 0.45 \mathrm{mg} / 1$. It can be seen in Fig. 8 that the highest fluorescence intensity is found in Sample No.3 (100\% WW) which is characterized by high peak C and M intensities which are degraded after irradiation. This finding is in accord with previous report (Seong-Nam and Gary 2008). The too low fluorescence intensities of protein-like peaks in all the EEMS shown in figures (Fig. 5, 6, 7 and Fig.8) are in accordance with the results of PARAFAC model shown in Fig.9 where there was no protein-like PARAFAC component was found.

\section{Parallel factor analysis (PARAFAC) of EEM data}

EEMs of fifteen samples (Table 1) for each irradiation day and for all the irradiation experiments (Exp.1, Exp.2, Exp.3 and Exp.4) have been decomposed using PARAFAC for a total of 648 EEMs. PARAFAC decomposition of 648 EEM dataset of all irradiation experiments (Table 2) gives three independent components which are validated by CORCONDIA $74.9 \%$ and split-half method. Fluorescence landscape of PARAFAC components (C1, C2 and C3) with corresponding excitation and the emission loadings are shown in Fig.9. It can be noticed that the nature of PARAFAC components seem to be present with varying contributions in every sample in the whole EEMs dataset of all Irradiation experiments. Excitation emission loadings of each component (C1, C2 and C3) were compared with Openfluor.org database and previously reported PARAFAC components in literature and their corresponding equivalents are shown in Table 3. C1 presented excitation maximum at $340 \mathrm{~nm}$ and an emission maximum at $430 \mathrm{~nm}$. Previous studies have associated this component to UV-A humic-like fluorophores and Peak C (Coble 1996) and peak “ $\propto$ (Parlanti et al. 2000). It represents terrestrial humic-like and it can be suggested that it is used as wastewater/nutrient enrichment tracer (Murphy et al. 2011). C2 showed excitation maximum at $375 \mathrm{~nm}$ and an emission maximum at 465 $\mathrm{nm}$. This component represents more humificated fluorophores and resembles $\mathrm{C} 2$ found in the study of (Abaker et al. 2018) and it is of fluvic-like fluorophores Peak A (Coble 1996). C3 excitation/emission peak was located at wavelengths of $295 / 405 \mathrm{~nm}$. This may be attributed to anthropogenic humic materials, agricultural and microbial component. This component C3 was defined in literature as marine humic-like peak M (Coble, 1996) and has 
accordance with previous reports (Murphy et al. 2008; Stedmon and Markager 2005). Furthermore, no protein-like

component was detected by PARAFAC which is validated by split-half method. The above-described PARAFAC

fluorescent components were used to reconstruct the original whole EEMs dataset and for multilinear regression between each component (i.e. C1, C2 and C3) and sample composition $\left(f_{\mathrm{SW}}\right.$ and $\left.f_{\mathrm{RW}}\right)$.

\section{Photochemical variation in fluorescent PARAFAC components}

Variation of C1, C2 and C3 in irradiation experiment Exp.4 before conducting multilinear regression indicates how the parameters of multilinear regression varies with irradiation process. Changes of maximum fluorescence intensity $F_{\max }$ of each PARAFAC components with irradiation time are shown in Fig.10. Fig.10 shows variations of $F_{\max }$ for $C 1$, C2 and C3 which decrease with irradiation process which is very clear for irradiated samples (shown in black). Whereas, for control samples (dark) (shown in dotted gray), $F_{\max }$ doesn't have a clear trend which explains the results presented in Fig.11. Similar trend has been found for the remaining irradiation experiments (Exp.1, Exp.2, Exp.3 and Exp.4) (data not shown). These findings suggest that photodegradation impact humic and fluvic-like fluorophores in water column in river and sea water. Additionally, SPOM may adsorb soluble organic matter from water resulting in a photoprotection to the DOM. This process may result in reducing photochemical degradation in which the fluorescence signal is not dramatically affected. In this regard, we suggest the following protection mode from suspended particulate organic matter. As many wastewater treatment plants use chlorine as a disinfectant material after secondary treatment and seawater in France is partly chlorinated (Péron and Courtot-Coupez 1980). Part of the added chlorine may undergo the following reaction either in treatment plants or receiving water bodies. Under sunlight, chlorine in effluent wastewater samples undergo the following reactions according to equations 3 and 4.

Photodegradation of $\mathrm{Cl}_{2}$ under sunlight produces free radicals of as shown in Eq. (3).

$$
C L-C L \rightarrow 2 C l *
$$

300 Free radicals produced in Eq. 3 react with oxygen to produce chlorine oxides may be classified in monochlor- and dichloroxi- derivatives as previously reported (Lopez et al., 1998) (Eq. 4)

All these compounds are thermally unstable and may decompose readily in atmosphere. Nevertheless, these reactions undergo continues reaction as shown in Eq. 5-6.

$$
2 \mathrm{Cl}_{2} \mathrm{O}_{4} \rightarrow \mathrm{Cl}_{2} \mathrm{O}_{7}+0.5 \mathrm{O}_{2}+\mathrm{Cl}_{2}
$$


These proposed reactions are in accordance with Lopez et al., 1998 who indicated formation of these photochemical reaction under exposure to light at wavelength of $366 \mathrm{~nm}$. So far, free radicals produced in Eq. 3 react with dissolved organic matter (Glucose, fatty acid and or protein) producing organochlorine compound according to Eq. (7)

$$
2 \mathrm{Cl} *+\mathrm{R}-\mathrm{CH}_{3} \rightarrow \mathrm{R}-\mathrm{CH}_{2} \mathrm{Cl}+\mathrm{HCl}
$$

312 These chlorinated hydrocarbons $\left(\mathrm{R}-\mathrm{CH}_{2} \mathrm{Cl}\right)$ are persistent in ecosystem and are able to absorb solar energy and release 313 it again into environment to go to its stable stage according to Eq. 8.

$314 \mathrm{R}-\mathrm{CH}_{2} \mathrm{CH}_{2} \mathrm{Cl}+\mathrm{Cl} *+$ light energy $\rightarrow \mathrm{R}-\mathrm{CHCH}_{2} \mathrm{Cl}+\mathrm{HCl} \rightarrow$

315 The produced compound $\mathrm{R}-\mathrm{CHCH}_{2} \mathrm{Cl}$ is fluorescent matter due to double bond formation. Where $\mathrm{R}$ can be an aliphatic 316 or aromatic moiety (Margulies et al. 1994). Presence of particulate matter in the system can reduce the rate of above317 mentioned reactions (3-8) but cannot stop them. The proposed reactions agree with previous reports (Morris 1978; El-

318 Nahhal et al. 1999 ; Nir et al. 2000 ; Muellner et al. 2007) and recent reports (Yuan et al. 2020)

319 Initial values of $\left(\mathbf{A}^{\mathrm{ww}_{*, 0}}, \mathbf{A}^{\mathrm{ww}_{*, 1},}, \mathbf{A}^{\mathrm{ww}_{*, 2}}\right)$ before irradiation

320 Values of multilinear regression coefficients for PARAFAC components (C1, C2 and C3) are given in table 4 for time zero, i.e. before the start of irradiation experiments, for all irradiation/mixing experiments. Multilinear regression between $(\mathrm{C} 1, \mathrm{C} 2$ and $\mathrm{C} 3)$ and $\left(f_{S W}, f_{R W}\right)$ shows excellent fitting since the power of correlation is high as indicated from values of $\mathrm{r}^{2}$ for each irradiation experiment as shown in table 4 . It can be seen that values of intercept $\left(\mathrm{A}^{\mathrm{ww}}{ }_{1,0}, \mathrm{~A}^{\mathrm{ww}_{2,0}}\right.$, $\left.\mathrm{A}^{\mathrm{Ww}}{ }_{3,0}\right)$ are of two order of magnitude higher than the absolute value of both coefficients of $f_{S W}\left(\mathrm{~A}^{\mathrm{ww}_{1,1}, \mathrm{~A}^{\mathrm{Ww}}}{ }_{2,1}\right.$,

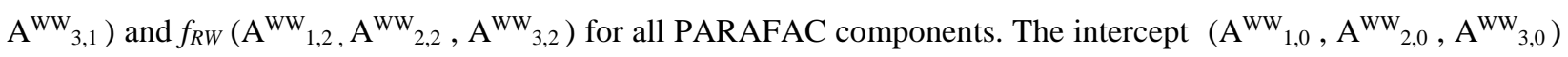
contains implicitly the impact of $f_{W W}$ on resulting fluorescence contribution of $(\mathrm{C} 1, \mathrm{C} 2$ and $\mathrm{C} 3)$ as explained thoroughly in the methodology section of this manuscript . This indicates that increasing $f_{S W}$ or $f_{R W}$ result in decreasing the resulting fluorescence contribution of (C1, C2 and C3). Additionally, it can be suggested that presence of particulate matter slows the intensity of photochemical degradation, this is quite obvious with the slight changes in samples that contains large fraction of suspended particulate matter compared with filtrated samples. Furthermore, suspended organic matter may adsorb dissolved organic matter on its surfaces and provide photoprotection from degradation. This phenomenon is in accordance with previous reports (EL-Nahhal et al. 2001; Nir et al. 2000; Margulies 1996) that revealed the ability of organoclay complexes to provide photoprotection to photodegradable pesticides. Moreover, filtration of samples may increase the contribution of fluorescence of mixing process is predominated by wastewater treatment plant for PARAFAC components and filtration has a measurable effect on multilinear regression parameters. When SPOM of only one water source is present, there is a decrease of values of the intercept parameter which suggest that there is an 
338 than that when SPOM from SW (i.e. Exp.3) is present suggesting that removal of fluorophores of river water plays a

339 role on values of intercept. In general, there is an influence of presence/absence of SPOM on the initial contribution

340 of multilinear regression parameters.

341 Rate order and kinetic constant determination for the photodegradation of Multilinear regression parameters

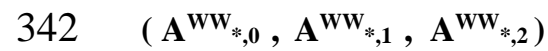

343 Kinetic constant and rate order of these parameters indicate how contribution of each PARAFAC component (Eq.2)

344 will evolve with irradiation time; hence EEM at any given point of irradiation time can be reconstructed. All irradiation

345 experiment (Exp.1, Exp.2, Exp.3 and Exp.4) showed continuous decrease of fluorescence signal with irradiation time

346 as shown in Fig.10. In comparison to other studies (Song et al. 2015; Zhu et al. 2017a), there was no increase of

347 fluorescence intensity found in this study. The decrease in values of $\left(\mathrm{A}^{\mathrm{Ww}_{*, 0},}, \mathrm{~A}^{\mathrm{Ww}_{*, 1},} \mathrm{~A}^{\mathrm{Ww} \mathrm{w}_{*}}\right)$ in all experiments

348 could be fit by second order reaction kinetics (Table 5) in agreement with previous works (Yang et al. 2014). Moreover,

349 values of kinetic constant (k) are presented in Fig.11(a). Wu et al. (2016) found pseudo-first order reaction kinetics for

350 the removal of fluorescence region volumes using fluorescence regional integration "FRI" which is in contrast with

our study where fluorescence EEMs were modelled by PARAFAC and multilinear regression was conducted between $f_{S W}$ and $f_{R W}$ and $(\mathrm{C} 1, \mathrm{C} 2$ and $\mathrm{C} 3)$. In addition, those authors used simulated solar light during $12 \mathrm{~h}$ and under 2.80 $\mathrm{mW} / \mathrm{cm}^{2}$ (visible) and $70.00 \mathrm{~mW} / \mathrm{cm}^{2}$. Second order reaction kinetics suggest that organic matter reacts with excited organic matter itself. Values of kinetic constant for $\left(\mathrm{A}^{\mathrm{ww}_{*, 0}}, \mathrm{~A}^{\mathrm{ww}_{*, 1}}, \mathrm{~A}^{\mathrm{Ww}_{*, 2}}\right)$ are shown in Fig.11(a). It can be seen from Fig.11(a) that values of kinetic constant for intercept $\mathrm{A}^{\mathrm{Ww}}{ }_{1,0}$ (Fig.10 a.1) is greater in $\mathrm{C} 1$ in Exp.1 compared to the remaining experiment and also in comparison to $\mathrm{A}^{\mathrm{Ww}} 2$ and $\mathrm{A}^{\mathrm{Ww}} \mathrm{w}_{3,0}$. In addition, same pattern can be seen in Exp.3 . Whereas for Exp.4 and Exp. 2, values of kinetic constant of $\mathrm{A}^{\mathrm{Ww}}{ }_{1,0}, \mathrm{~A}^{\mathrm{Ww}}{ }_{2,0}$ and $\mathrm{A}^{\mathrm{Ww}}{ }_{3,0}$ are almost near zero which are negligible. For kinetic constant $\mathrm{k}$ of $\mathrm{A}^{\mathrm{WW}_{1,1}}, \mathrm{~A}^{\mathrm{wW}_{2,1}}$ and $\mathrm{A}^{\mathrm{Ww}_{3,1}}$ ( representing the impact of $f_{S W}$ ) (Fig.11 a.2 ) showed similar trend in Exp.1 and Exp.3 compared to Exp. 4 and Exp. 2 (their values also negligible) . Moreover, kinetic constant $\mathrm{k}$ of $\mathrm{A}^{\mathrm{WW}_{1,2}, \mathrm{~A}^{\mathrm{WW}}}$ and $\mathrm{A}^{\mathrm{WW}_{3,2}}$ (representing the impact of $f_{R W}$ ) are shown in Fig.11 (a.3). Same trend can be seen as mentioned above however with higher values of $\mathrm{k}$ compared to values of $\mathrm{k}$ for $\mathrm{A}^{\mathrm{ww}}{ }_{1,1}, \mathrm{~A}^{\mathrm{ww}} \mathrm{w}_{2,1}$ and $\mathrm{A}^{\mathrm{WW}} 3$. Negative values for $\mathrm{k}$ in the middle and right figures represent the negative impact of $f_{S W}$ and $f_{R W}$ on fluorescence signal of $\mathrm{C} 1, \mathrm{C} 2$ and $\mathrm{C} 3$. The higher values of $\mathrm{k}$ for the coefficient of $f_{R W}$ suggest that increasing the percentage of river water in sample leads to faster photodegradation than increasing $f_{S W}$ concentration in sample. The lowest values of $\mathrm{k}$ for all $\mathrm{C} 1, \mathrm{C} 2$ and $\mathrm{C} 3$ are found for $\mathrm{A}^{\mathrm{Ww}}{ }_{1,0}, \mathrm{~A}^{\mathrm{Ww}}{ }_{2,0}$ and $\mathrm{A}^{\mathrm{ww}} \mathrm{w}_{3,0}$ which are the intercept of multilinear regression and implicitly retain information about the impact of $f_{W W}$. This suggests that increasing $f_{W W}$ in sample retards 
368 Accordingly, $f_{W W}$ contribution is refractory and resilient under long irradiation. Zhu et al. (2017b) found similar results 369 between mixing of terrestrial and autochthonous organic matter. Wu et al. (2016) observed little variations between 370 humic-like and protein-like fluorophores in reclaimed water under strong conditions of irradiation. Kinetic constant 371 (k) is highest when SPOM of WW and SW were present (Exp.1 and Exp.3) which imply that SPOM from these WW 372 and SW makes the photodegradation faster for C1 and C2 and C3. Impact of SPOM from RW, SW and WW varies 373 according to fluorescent PARAFAC component. The nature of these SPOM should be investigated more in order to 374 understand their role in photodegradation. Advanced SPOM separation or extraction and fractionation techniques 375 should be used (e.g. XAD resins). Evolution with irradiation of initial values of $\left(\mathrm{A}^{\mathrm{ww}_{*, 0},} \mathrm{~A}^{\mathrm{ww}_{*, 1},} \mathrm{~A}^{\mathrm{ww}_{*, 2}}\right)$ before 376 irradiation for each corresponding PARAFAC component can be tracked using the values of their corresponding 377 kinetic constants hence reconstruction of fluorescence signal of $\mathrm{C} 1, \mathrm{C} 2$, and $\mathrm{C} 3$ can be conducted hence the whole 378 EEM of sample. Therefore, a dynamic model has been developed for the photodegradation of SPOM from different water types. No clear behavior for control dark samples was found due to biological activity (Yang et al. 2014); except the mean contributions relative deviation standard (RSD) and this is consistent with results shown above in Fig.10. Relative Standard deviation (RSD) of parameters of multilinear regression are shown in Fig.11(b). RSD values in Exp.4 are the smallest compared to all other irradiation experiments. This finding could be due to synergic effect of the microbial activity coming simultaneously from all the water types (RW, SW and WW). RSD values for C3 coefficients of multilinear regression are higher for all irradiation experiments compared to those of $\mathrm{C} 1$ and $\mathrm{C} 2$. The greater RSD value of $\mathrm{C} 3$ for all coefficients can be interpreted as having chaotic variations. Another observation is that RSD values for $\mathrm{C} 1$ and $\mathrm{C} 2$ have an order of Exp. $1>$ Exp. $2>$ Exp. $3>$ Exp. 4 . SPOM from WW seems to be responsible for variation with a greater degree compared to SPOM from SW and RW. Compared to irradiation experiment (Exp.4), the synergistic effect of all SPOM makes RSD values to be the smallest possible. This observation could be attributed to the fact that SPOM from each water type and microorganisms are competing which therefore stabilize fluorescence signal in non-sterile dark control. These data indicate statistical differences between control group and those exposed to sunlight during different time of year.

\section{Conclusions}

393 The rationale of this study emerges from the need to develop previous models for the prediction of fluorescence signal 394 of anthropogenic DOM based on mixing composition of sample and to study the impact of presence/absence of suspended particulate matter of three water types (River water RW, Seawater SW, effluent wastewater WW) on the resulting fluorescence signal of their mixtures and to simulate their natural mixing. Four Mixing and Irradiation 
irradiation and presence/absence of suspended particulate matter from three water types (river water RW, seawater

SW, effluent wastewater WW) were studied using three-dimensional fluorescence spectroscopy coupled with parallel factor analysis EEM-PARAFAC. Evolution of fluorescence signal of PARAFAC components was investigated kinetically through kinetic evolution of multilinear regression parameters with irradiation. Three components (C1,C2 and C3) might be extracted from the whole EEM dataset of all irradiation experiments. Protein-like component might not be found which is due to its very low fluorescence intensity in the whole dataset. Second order kinetics were found for all parameters (intercept, coefficient of $f_{S W}$ and coefficient of $f_{R W}$ ) indicating bimodal reaction of organic matter with itself and excited organic matter. It can be concluded that SPOM of one water type has profound impact on the resulting kinetic constants of multilinear regression parameters. Kinetic constants of $\left(\mathrm{A}^{\mathrm{WW}}\right.$ *, “i.e. intercept", $\mathrm{A}^{\mathrm{WW}_{*, 1}}$

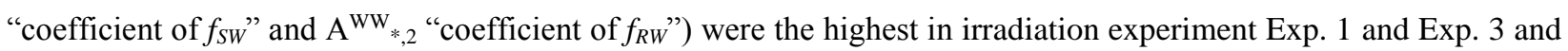

the lowest in Exp. 4 and Exp.2. Thus, this study is a further step on the development of online or real time models of evolution of fluorescence signal coming from anthropogenic sources. Further studies are warranted for the application of this model on other urban river systems.

\section{Acknowledgements}

412 This work was funded by Hermes Program - from European commission through its Erasmus Mundus foundation; in

413 addition to the funding from Campus France through its research grant Al Maqdisi PHC Project $\mathrm{n}^{\circ}$ 40229SD.

414 Moreover, we are thankful toward Christian Martino and Gael Durrieu for being available in each sampling campaign.

\section{Compliance with ethical standards}

\section{Conflict of interest}

417 The authors declare no conflict of interest

\section{Author Contributions}

419 Ibrahim EL-Nahhal: Funding acquisition, Conceptualization, Methodology, Writing- Reviewing and Editing Ro420 land Redon: Software -Reviewing Michel Raynaud: Software -Reviewing Yasser EL-Nahhal: Funding acquisition, 421 Reviewing and Editing Stéphane Mounier: Funding acquisition, Supervision, Project administration, Reviewing and 422 Editing. All authors read and approved the final manuscript.

\section{References}

424 Abaker M G, Domeizel M, Mouloubou O R, Rapetti N, Mounier S (2018) UV-Visible and Fluorescence Green Waste Composts Monitoring: Material Dependency. Compost Sci Util 26(3):177-188. https://doi.org/10.1080/1065657X.2018.1434023

Akkanen J, Vogt R D, Kukkonen J V K (2004) Essential characteristics of natural dissolved organic matter affecting 

0705-x

Baker A, Spencer R G M (2004) Characterization of dissolved organic matter from source to sea using fluorescence and absorbance spectroscopy. Sci Total Environ 33:217-232. https://doi.org/10.1016/j.scitotenv.2004.04.013

Baker A, Tipping E, Thacker S A, Gondar D (2008). Relating dissolved organic matter fluorescence and functional properties. Chemosphere 73(11):1765-1772. https://doi.org/10.1016/j.chemosphere.2008.09.018

Boyd T J, Osburn C L (2004) Changes in CDOM fluorescence from allochthonous and autochthonous sources during tidal mixing and bacterial degradation in two coastal estuaries. Mar Chem 89:189-210. https://doi.org/10.1016/j.marchem.2004.02.012

Bro R 1998 Multi-way Analysis in the Food Industry. Ph.D. dissertation, University of Amsterdam. Retrieved from : http://www.models.kvl.dk/sites/default/files/brothesis_0.pdf

Callahan J, Dai M, Chen R F, Li X, Lu Z, Huang W (2004) Distribution of dissolved organic matter in the Pearl river estuary, China. Mar Chem 89:211-224. https://doi.org/10.1016/j.marchem.2004.02.013

Chin W C, Orellana M V, Verdugo P (1998). Spontaneous assembly of marine dissolved organic matter into polymer gels. Nature 391:568-572. https://doi.org/10.1038/35345

Coble P G (1996) Characterization of marine and terrestrial DOM in seawater using excitation-emission matrix spectroscopy. Mar Chem 51(4):325-346. https://doi.org/10.1016/0304-4203(95)00062-3

Cohen E, Levy G J, Borisover M (2014) Fluorescent components of organic matter in wastewater: efficacy and selectivity of the water treatment. Water Res 55:323-334. https://doi.org/10.1016/j.watres.2014.02.040

Dalzell B J, Minor E C, Mopper K M (2009) Photodegradation of estuarine dissolved organic matter: an assessment of DOM transformation. Org Geochem 40:253-257. https://doi.org/10.1016/j.orggeochem.2008.10.003

De Souza Sierra M M, Donard O F X (1991) Simulation of fluorescence variability in estuaries. Oceanologica Acta $11: 275-284$

EL-Nahhal I, Redon R, Raynaud M, EL-Nahhal Y, Mounier S (2020) Characterization of the fate and changes of postirradiance fluorescence signal of filtered anthropogenic effluent dissolved organic matter from wastewater treatment plant in the coastal zone of Gapeau river. Environ Sci Pollut Res 27:23141-23158 https://doi.org/10.1007/s11356-020-08842-w

El-Nahhal Y, Nir S, Margulies L, Rubin B (1999) Reduction of photodegradation and volatilization of herbicides in organo-clay formulations. Appl Clay Sci 14:105-119. https://doi.org/10.1016/S0169-1317(98)00053-2

Estapa M L, Mayer L M (2010) Photooxidation of particulate organic matter, carbon/oxygen stoichiometry, and 
Gagné J P, Tremblay L (2009) Organic matter distribution and reactivity in the waters of a large estuarine system. Mar Chem 116(1-4):1-12. https://doi.org/10.1016/j.marchem.2009.09.006

He W, Chen M, Schlautman M A, Hur J (2016) Dynamic exchanges between DOM and POM pools in coastal and inland aquatic ecosystems: A review. Sci Total Environ 551-552:415-428. https://doi.org/10.1016/j.scitotenv.2016.02.031

Her N, Amy G, McKnight D, Sohn J, Yoon Y (2003) Characterization of DOM as a function of MW by fluorescence EEM and HPLC-SEC using UVA, DOC, and fluorescence detection. Water Res 37(17):4295-4303. https://doi.org/10.1016/S0043-1354(03)00317-8

Hirose K (2007) Metal-organic matter interaction: ecological roles of ligands in oceanic DOM. Appl Geochem 22:1636-1645. https://doi.org/10.1016/j.apgeochem.2007.03.042

Ishii S K, Boyer T H (2012) Behavior of reoccurring PARAFAC components in fluorescent dissolved organic matter in natural and engineered systems: a critical review. Environ Sci Technol 46(4):2006-2017. https://doi.org/10.1021/es2043504

Kowalczuk P, Cooper W J, Whitehead R F, Durako M J, Sheldon W (2003) Characterization of CDOM in an organicrich river and surrounding coastal ocean in South Atlantic Bight. Aquat Sci 65:384-401. https://doi.org/10.1007/s00027-003-0678-1

Laane R W P M, Kramer K J M (1990) Natural fluorescence in the North Sea and its major estuaries. Netherlands J Sea Res 26:1-9. https://doi.org/10.1016/0077-7579(90)90052-I

Lapierre J F, del Giorgio P A (2014) Partial coupling and differential regulation of biologically and photochemically labile dissolved organic carbon across boreal aquatic networks. Biogeosciences 11(20):5969-5985. https://doi.org/10.5194/bg-11-5969-2014

Lawaetz A J, Stedmon C A (2009) Fluorescence intensity calibration using the Raman scatter peak of water. Appl Spectrosc 63(8):936-940. https://doi.org/10.1366/000370209788964548

Leppard GG, West MM, Flannigan DT, Carson J, Lott J (2011) A classification scheme for marine organic colloids in the Adriatic Sea: colloid speciation by transmission electron microscopy. Can J Fish Aquat Sci 54(10):23342349

Liu Q Y, Shank G C (2015) Solar radiation-enhanced dissolution (photodissolution) of particulate organic matter in Texas estuaries. Estuaries Coasts 38 (6):2172-2184. https://doi.org/10.1007/s12237-014-9932-0 
Lopez L M, Croce E A, Sicre E J (1998) The photochemical reaction between chlorine and chlorine perchlorate at 366 nm J Photochem Photobiol A Chem 112:97-102. https://doi.org/10.1016/S1010-6030(97)00276-1

Margulies L, Rosen H, Stern T, Rytwo G, Rubin B, Ruso L, Nir S, Cohen E (1993) Photostabilization of pesticides by clays and chromophores. Arch Insect Biochem Physiol 22:467-486. https://doi.org/10.1002/arch.940220313

Mayer L M, Schick L L, Skorko K, Boss E (2006) Photodissolution of particulate organic matter from sediments. Limnol Oceanogr 51 (2):1064-1071. https://doi.org/10.4319/lo.2006.51.2.1064

McCallister S L, Bauer J E, Canuel E A (2006a) Bioreactivity of estuarine dissolved organic matter: A combined geochemical and microbiological approach. Limnol Oceanogr 51(1):94-100. https://doi.org/10.4319/lo.2006.51.1.0094

McCallister S L, Bauer J E, Ducklow H W, Canuel E A (2006b) Sources of estuarine dissolved and particulate organic matter: A multi-tracer approach. Org Geochem 37(4):454-468. https://doi.org/10.1016/J.ORGGEOCHEM.2005.12.005

Micó P, García-Ballesteros S, Mora M, Vicente R, Amat A M, Arques A (2019) EEMlab: A graphical user-friendly interface for fluorimetry experiments based on the drEEM toolbox. Chemometr Intell Lab Syst 188:6-13. https://doi.org/10.1016/J.CHEMOLAB.2019.03.001

Mopper K, Kieber D J, Stubbins A (2014) Marine Photochemistry of Organic Matter: Processes and Impacts. Processes and Impacts. In Biogeochemistry of Marine Dissolved Organic Matter: Second Edition (pp. 389-450). https://doi.org/10.1016/B978-0-12-405940-5.00008-X

Morris J C (1978) The chemistry of aqueous chlorine in relation to water chlorination. In: Jolleys, R.L. (Ed.), Water Chlorination: Environmental Impact and Health Effects, vol. 1. Ann Arbor Science Publishers, Michigan, pp. $21-35$.

Muellner M G, Wagner E D, Mccalla K, Richardson S D, Woo Y T, Plewa M J (2007) Haloacetonitriles vs. regulated haloacetic acids: are nitrogen-containing DBFs more toxic? Environ Sci Technol 41(2):645-651. https://doi.org/10.1021/es0617441

Murphy K R, Hambly A, Singh S, Henderson R K, Baker A, Stuetz R, Khan S J (2011) Organic Matter Fluorescence in Municipal Water Recycling Schemes: Toward a Unified PARAFAC Model. Environ Sci Technol 45(7):2909_ 2916. https://doi.org/10.1021/es103015e

Murphy K R, Stedmon C A, Graeber D, Bro R (2013) Fluorescence spectroscopy and multi-way techniques. PARAFAC. Anal Methods 5(23):6557. https://doi.org/10.1039/c3ay41160e

Murphy K R, Stedmon C A, Waite T D, Ruiz G M (2008) Distinguishing between terrestrial and autochthonous 
organic matter sources in marine environments using fluorescence spectroscopy. Mar Chem 108(1-2):40-58. https://doi.org/10.1016/j.marchem.2007.10.003

Nir S, Undabeytia T, Yaron D, El-Nahhal Y, Polubesova T, Serban S, Rytwo G, Lagaly G, Rubin B (2000) cations: Interaction between phenyl rings. Environ Sci Technol 34:1269-1274. https://doi.org/10.1021/es9903781

Ohno T (2002) Fluorescence inner-filtering correction for determining the humification index of dissolved organic matter. Environ Sci Technol 36(4):742-746. https://doi.org/10.1021/es0155276

Osburn C L, Handsel L T, Mikan M P, Paerl H W, Montgomery M T (2012) Fluorescence tracking of dissolved and particulate organic matter quality in a river-dominated estuary. Environ Sci Technol 46(16):8628-8636. https://doi.org/10.1021/es3007723

Parlanti E, Wörz K, Geoffroy L, Lamotte M (2000) Dissolved organic matter fluorescence spectroscopy as a tool to estimate biological activity in a coastal zone submitted to anthropogenic inputs. Org Geochem 31(12):17651781. https://doi.org/10.1016/S0146-6380(00)00124-8

Patel-Sorrentino N, Mounier S, Benaim J Y (2002) Excitation-emission fluorescence matrix to study pH influence on organic matter fluorescence in the Amazon basin rivers. Water Res 36(10):2571-2581. https://doi.org/10.1016/s0043-1354(01)00469-9

Péron A,Courtot-Coupez J (1980) Etude physicochimique de la chloration de l'eau de mer artificielle. Water Res 14(4):329-332. https://doi.org/10.1016/0043-1354(80)90079-2

Pisani O, Yamashita Y, Jaffe R (2011) Photo-dissolution of flocculent, detrital material in aquatic environments: contributions to the dissolved organic matter pool. Water Res 45 (13):3836-3844. https://doi.org/10.1016/j.watres.2011.04.035

Riggsbee J A, Orr C H, Leech D M, Doyle M W, Wetzel R G (2008) Suspended sediments in river ecosystems: photochemical sources of dissolved organic carbon, dissolved organic nitrogen, and adsorptive removal of dissolved iron. J Geophys Research-Biogeosciences 113(G3):019. https://doi.org/10.1029/2007JG000654

Seong-Nam N, Gary A (2008) Differentiation of Wastewater Effluent Organic Matter (EfOM) From Natural Organic Matter (NOM) Using Multiple Analytical Techniques. Water Sci Technol 57(7). https://doi.org/10.2166/WST.2008.165

Sgroi M, Gagliano E, Vagliasindi F, Roccaro P (2020) Inner filter effect, suspended solids and nitrite/nitrate interferences in fluorescence measurements of wastewater organic matter. Sci Total Environ 711:134663. 
https://doi.org/10.1016/j.scitotenv.2019.134663

548 Søndergaard M, Thomas D N (2004) Dissolved Organic Matter (DOM) in Aquatic Ecosystems: A Study of European Catchments and Coastal Waters. EU Project DOMAINE 87-89143-25-6.

550 Song W, Zhao C, Mu S, Pan X, Zhang D, Al-Misned F A, Mortuza M G (2015) Effects of irradiation and pH on

Stedmon C A, Bro R (2008) Characterizing dissolved organic matter fluorescence with parallel factor analysis: A

Stedmon C A, Markager S (2005) Resolving the variability in dissolved organic matter fluorescence in a temperate estuary and its catchment using PARAFAC analysis. Limnol Oceanogr 50(2):686-697. https://doi.org/10.4319/lo.2005.50.2.0686

Stedmon C A, Markager S, Bro R (2003) Tracing dissolved organic matter in aquatic environments using a new approach to fluorescence spectroscopy. Mar Chem 82(3-4):239-254. http://dx.doi.org/10.1016/s03044203(03)00072-0

Tucker S A, Amszi V L, Acree W E (1992) Primary and secondary inner filtering: effect of K2Cr2O7 on fluorescence emission intensities of quinine sulfate. J Chem Educ 69:A8-A12. https://doi.org/10.1021/ed069pA8

Wu Q, Li C, Wang W, He T, Hu H, Du Y, Wang T (2016) Removal of fluorescence and ultraviolet absorbance of dissolved organic matter in reclaimed water by solar light. $\mathbf{J}$ Environ Sci 43:118-127. https://doi.org/10.1016/J.JES.2015.08.021

Wünsch U J, Murphy K R, Stedmon C A (2017) The One-Sample PARAFAC Approach Reveals Molecular Size Distributions of Fluorescent Components in Dissolved Organic Matter. Environ Sci Technol 51(20):1190011908. https://doi.org/10.1021/acs.est.7b03260

Yang X, Meng F, Huang G, Sun L, Lin Z (2014) Sunlight-induced changes in chromophores and fluorophores of wastewater-derived organic matter in receiving waters - The role of salinity. Water Res 62:281-292. https://doi.org/10.1016/J.WATRES.2014.05.050

Zepp R G, Sheldon W M, Moran M A (2004) Dissolved organic fluorophores in southeastern US coastal waters: correction method for eliminating Rayleigh and Raman scattering peaks in excitation-emission matrices. Mar 
578 Zhu W Z, Yang G P, Zhang H H (2017a) Photochemical behavior of dissolved and colloidal organic matter in estuarine and oceanic waters. Sci Total Environ 607-608:214-224. https://doi.org/10.1016/J.SCITOTENV.2017.06.163

Zhu W Z, Zhang J, Yang G P (2017b) Mixing behavior and photobleaching of chromophoric dissolved organic matter in the Changjiang River estuary and the adjacent East China Sea. Estuar Coast Shelf Sci https://doi.org/10.1016/J.ECSS.2017.07.019

\section{Figures Captions}

Fig. 1 Ternary diagram of the mixing percentages of three endmember mixing components (freshwater (RW), wastewater treatment plant (WW), seawater (SW)). Each red point represents a solution that contains the mentioned and calculated percentages of each water source (endmember)

Fig. 2 The used apparatus for all the irradiation experiments which was on the rooftop of MIO laboratory/ University of Toulon-France. GPS location: ( $\left.43^{\circ} 08^{\prime} 11.2^{\prime \prime} \mathrm{N} 6^{\circ} 01^{\prime} 16.7^{\prime \prime} \mathrm{E}\right)$

602 Fig. 5 EEMs of Samples 1,2,3 in Irradiation experiment Exp.1

603 Fig. 6 EEMs of Samples 1,2,3 in irradiation experiment Exp.2

604 Fig. 7 EEMs of Samples 1,2,3 in Irradiation experiment Exp.3

605 Fig. 8 EEMs of Samples 1,2,3 in Irradiation experiment Exp.4

606 Fig. 9 Fluorescence landscape of PARAFAC components identified from the decomposition of all EEM datasets on 

study on the right. Excitation loading for CP/PARAC component are shown in solid lines whereas emission loadings are shown in dotted lines

610 Fig. 10 Changes in the maximum fluorescence intensity of all four PARAFAC components (C1, C2, C3 and C4) 611 during Irradiation experiment Exp.4 . All Exp.1, Exp.2, Exp.3 showed the same pattern

612 Fig. 11 (a) Kinetic constant for coefficients of multilinear regression for C1,C2 and C3 PARAFAC components. (b) 613 The relative standard deviation (RSD) values for all the multilinear regression coefficients (intercept, coefficient 614 of $f_{S W}$, coefficient of $f_{R W}$ ) for the control dark samples in all the irradiation experiments 


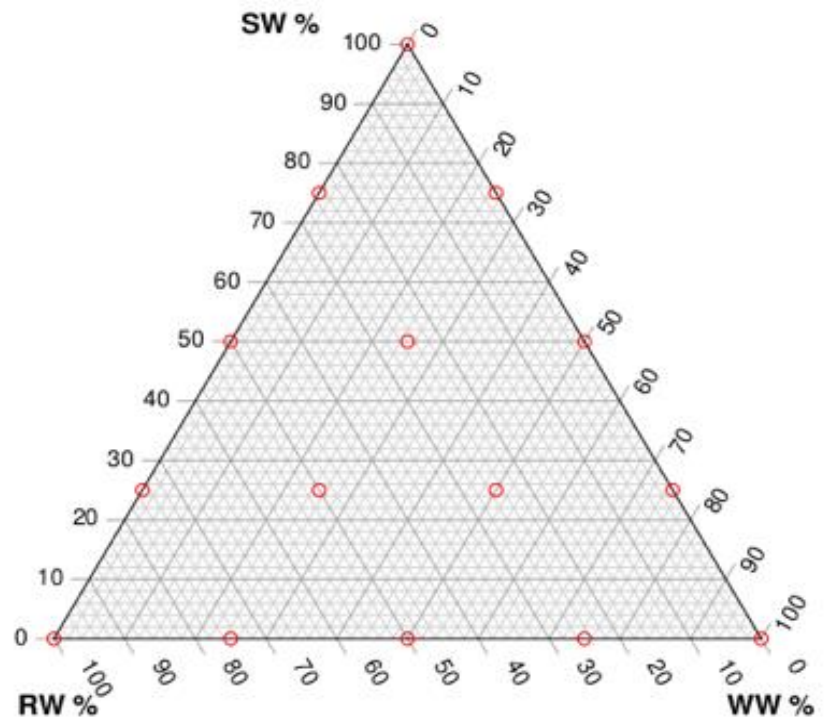

Fig. 1

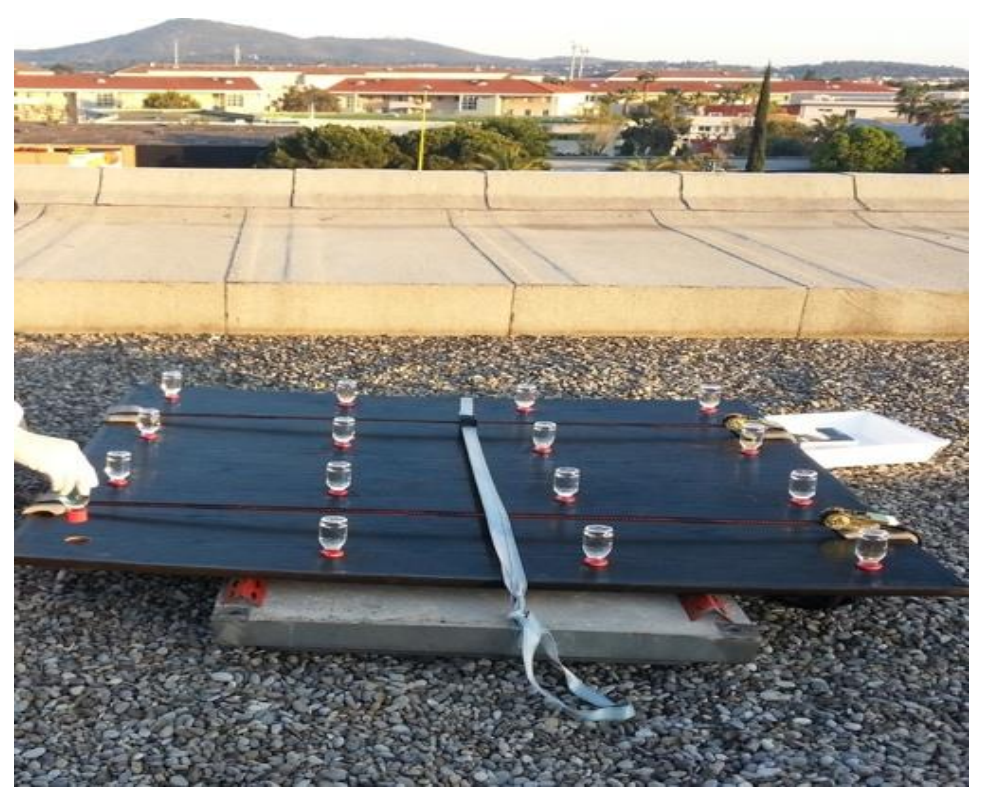

Fig. 2 


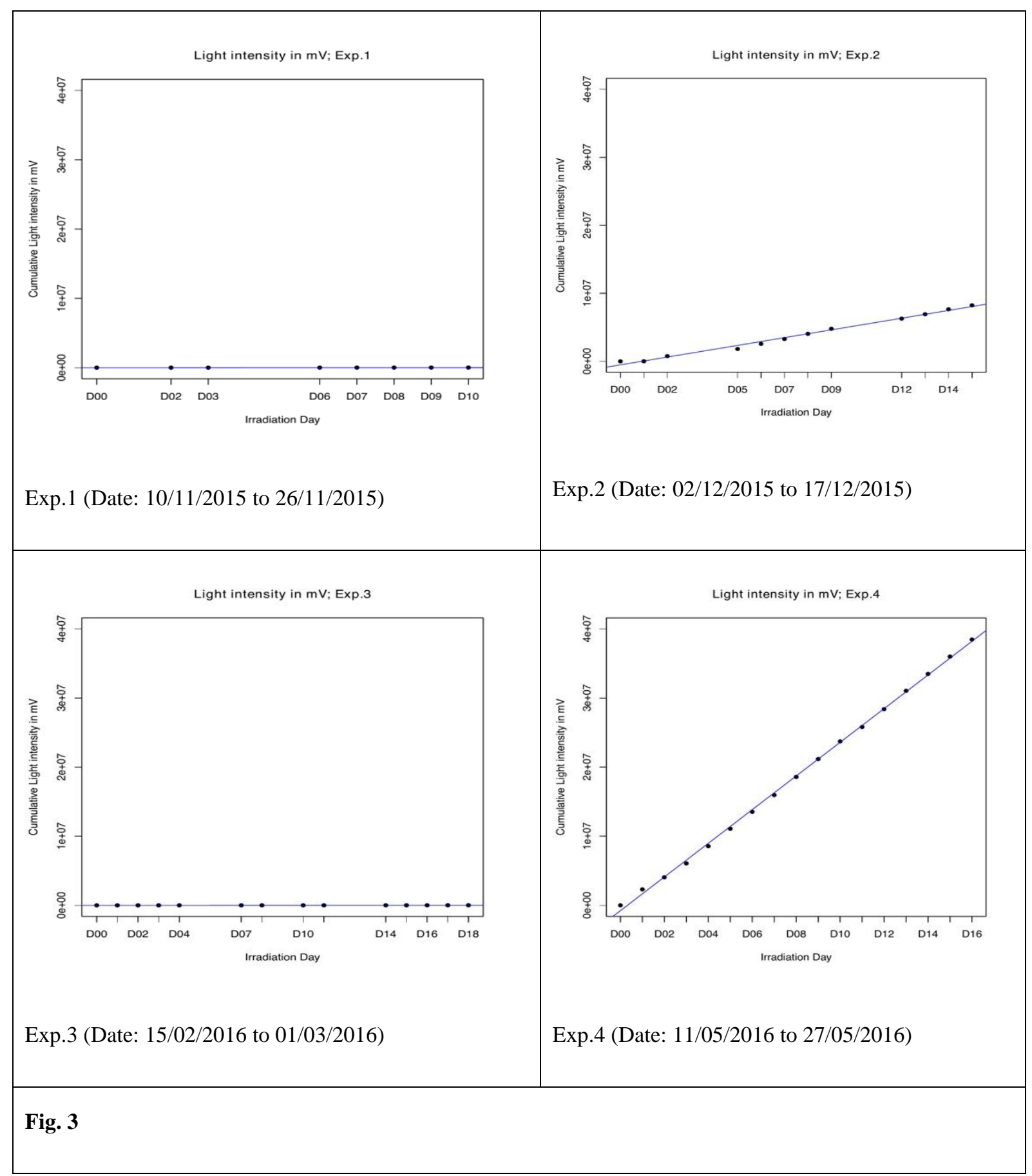




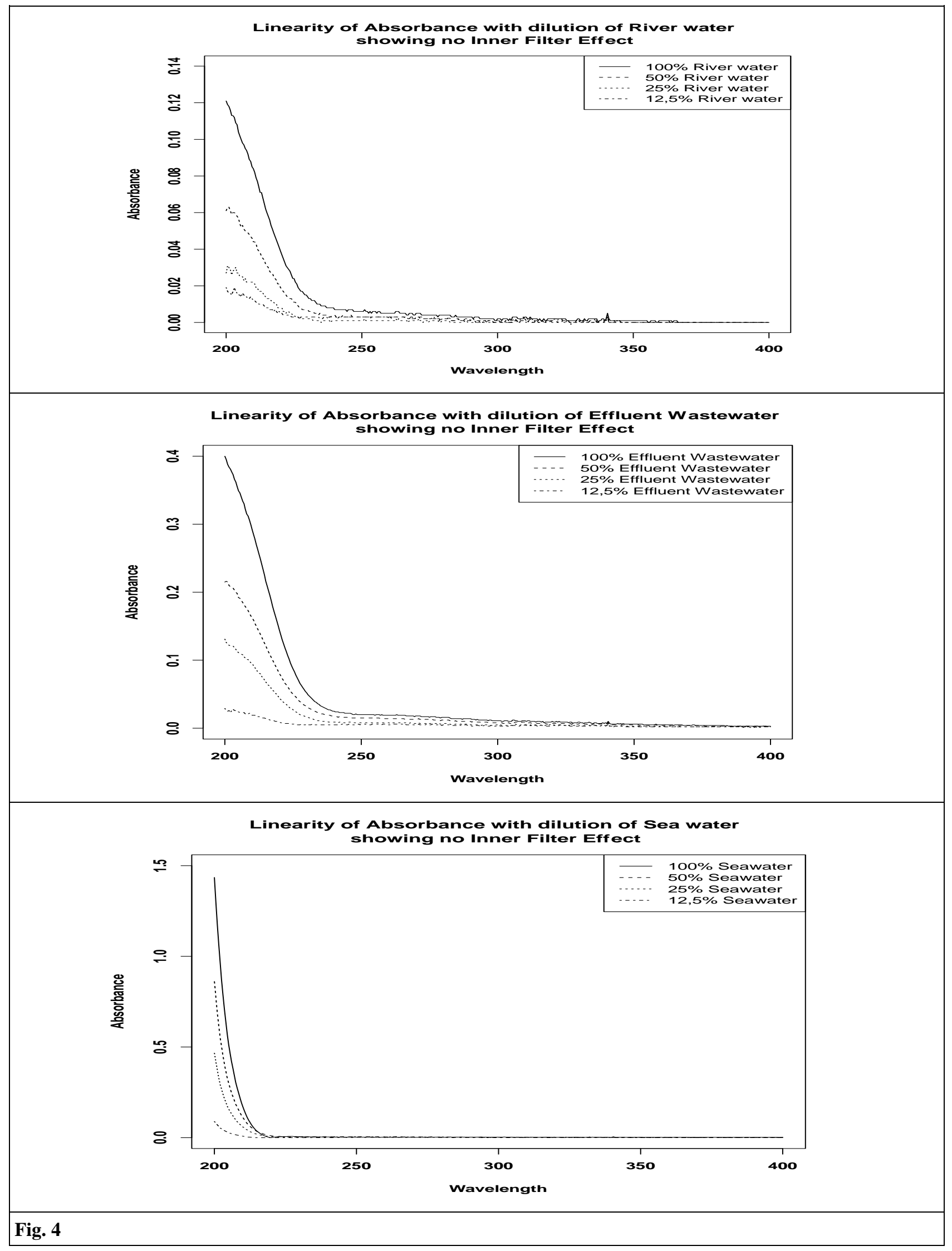




\begin{tabular}{|c|c|c|c|}
\hline & Before Irradiation & After Irradiation & $\begin{array}{l}\text { Before Irradiation - After } \\
\text { Irradiation }\end{array}$ \\
\hline $\begin{array}{l}\text { Samp } \\
\text { le } \\
\text { No.1 } \\
\text { (RW) }\end{array}$ & 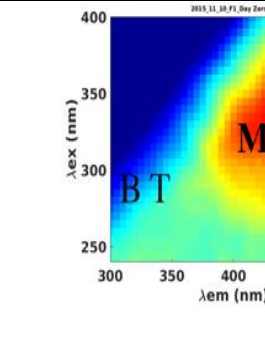 & 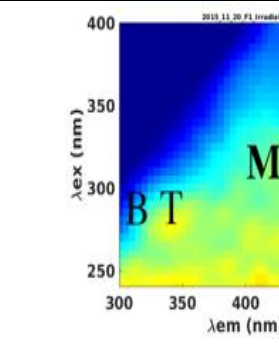 & 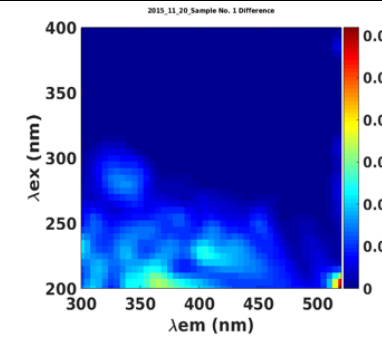 \\
\hline $\begin{array}{l}\text { Samp } \\
\text { le } \\
\text { No.2 } \\
\text { (SW) }\end{array}$ & $\begin{array}{lll}{ }_{300}^{250} & & \\
{ }_{300}^{400} & \operatorname{sem}(\mathrm{nm})\end{array}$ & 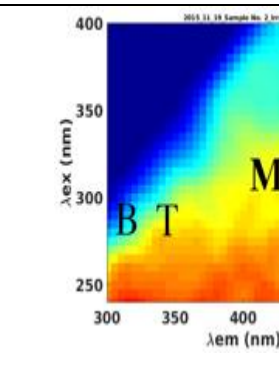 & 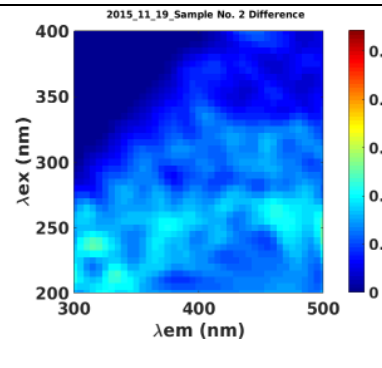 \\
\hline $\begin{array}{l}\text { Samp } \\
\text { le } \\
\text { No.3 } \\
\text { (WW } \\
\text { ) }\end{array}$ & 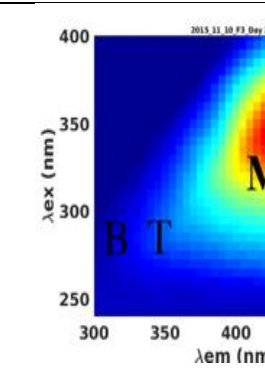 & 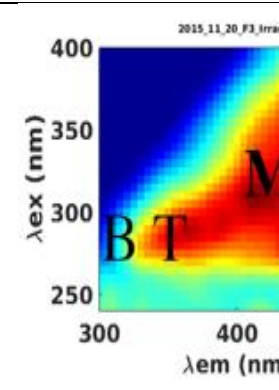 & 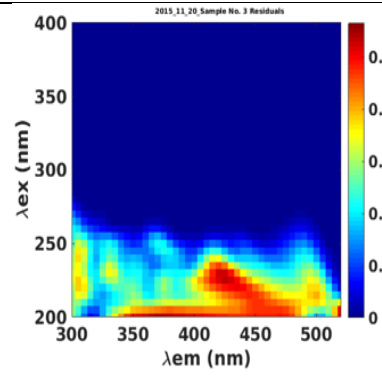 \\
\hline Fig. & & & \\
\hline
\end{tabular}

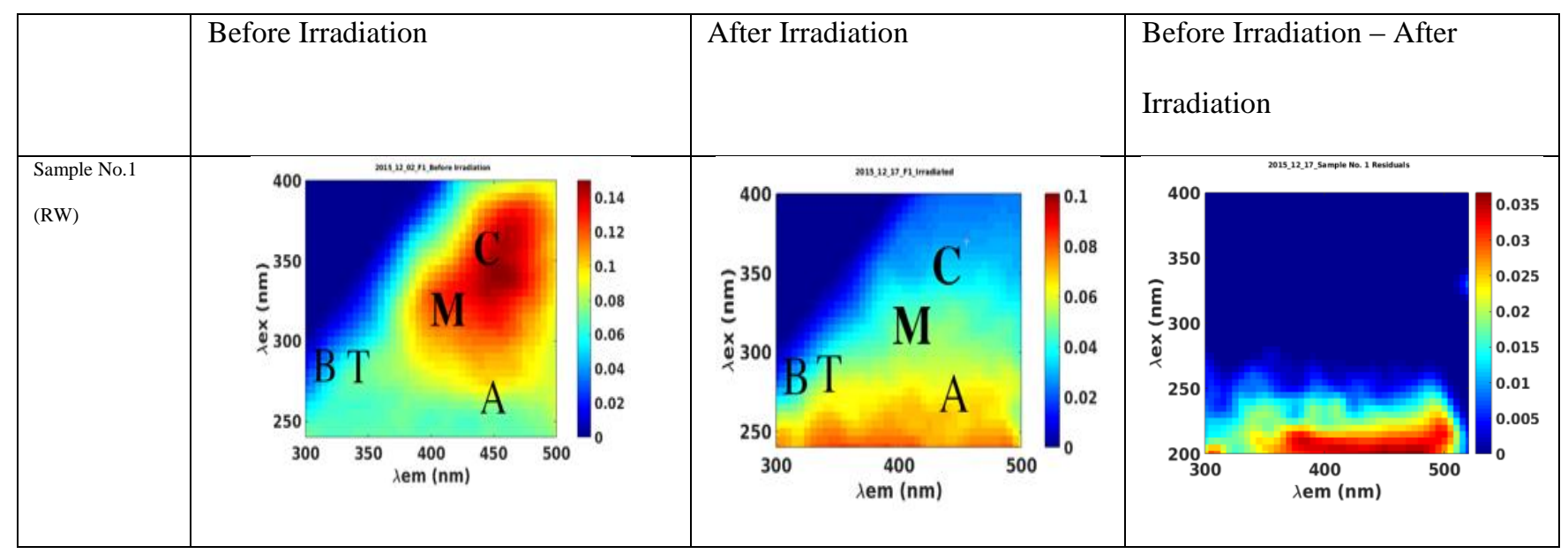




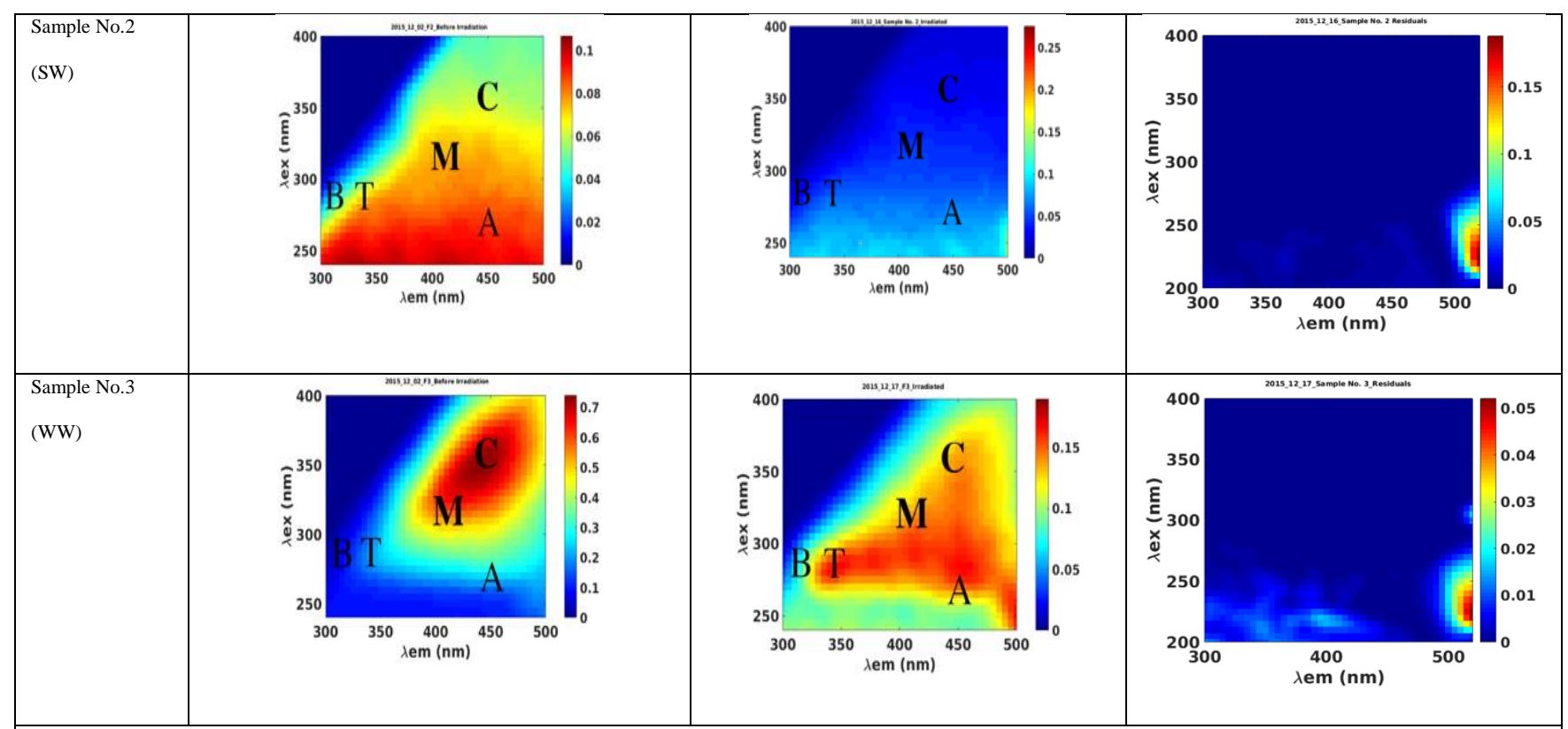

Fig. 6

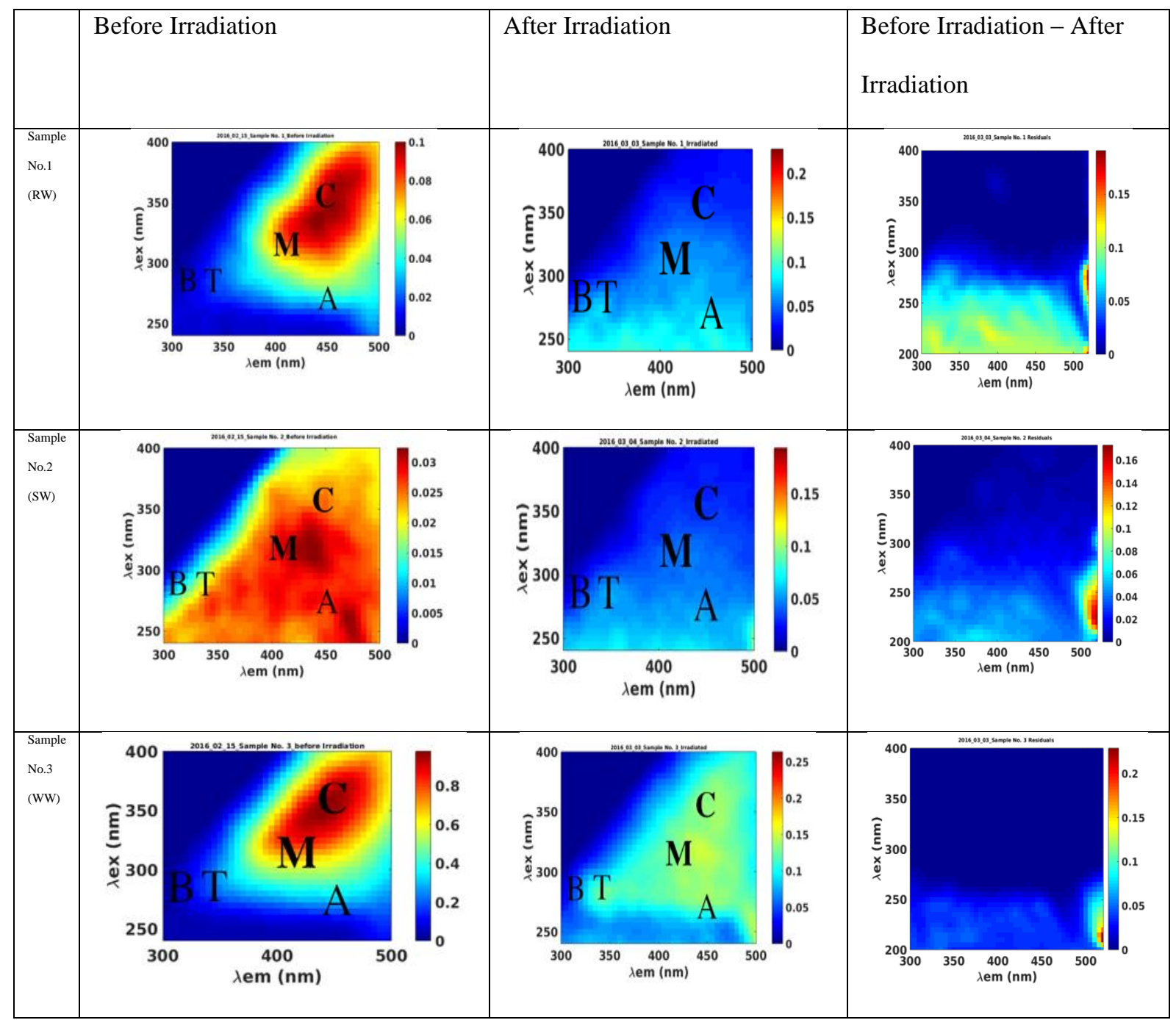


Fig. 7

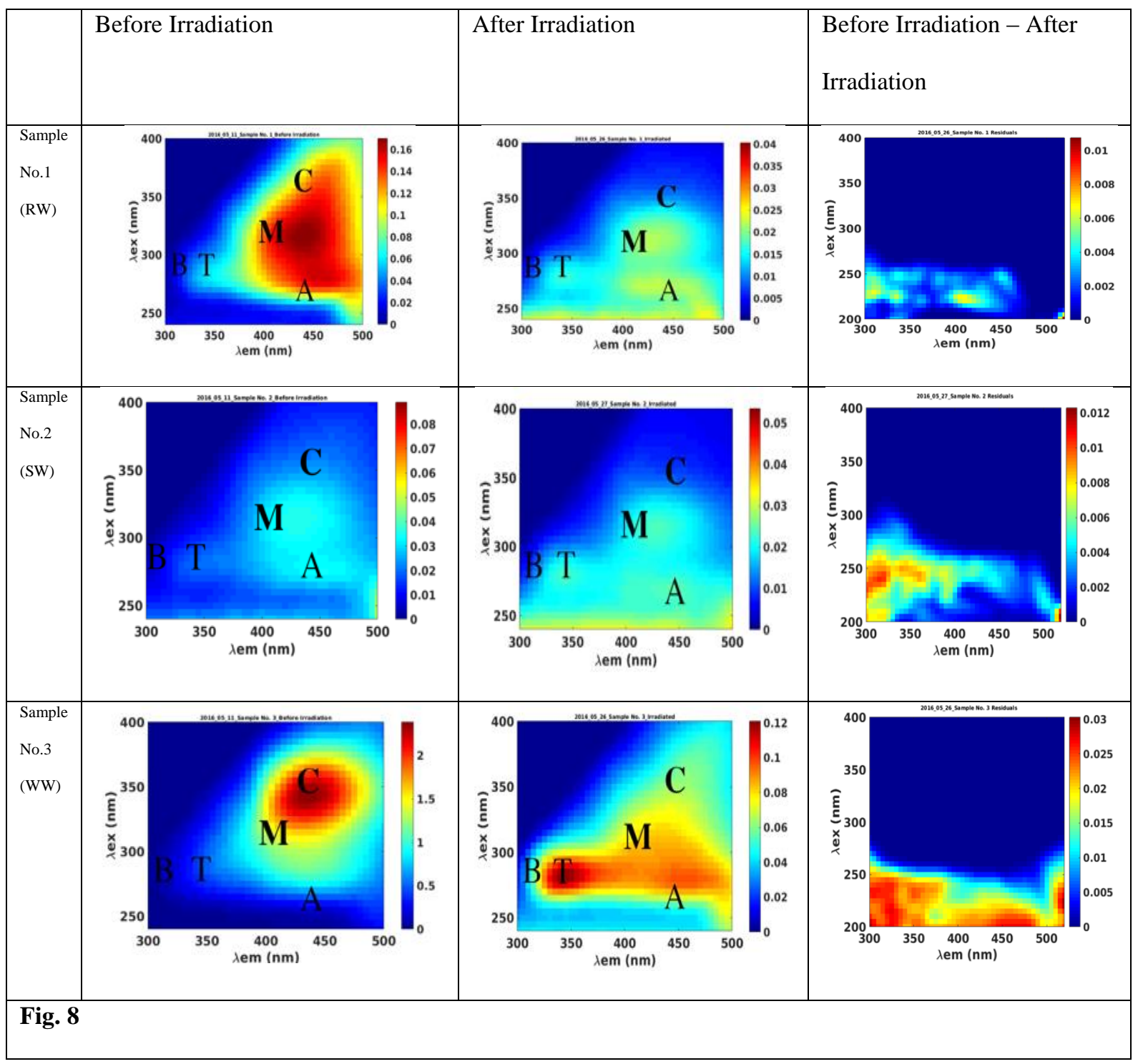




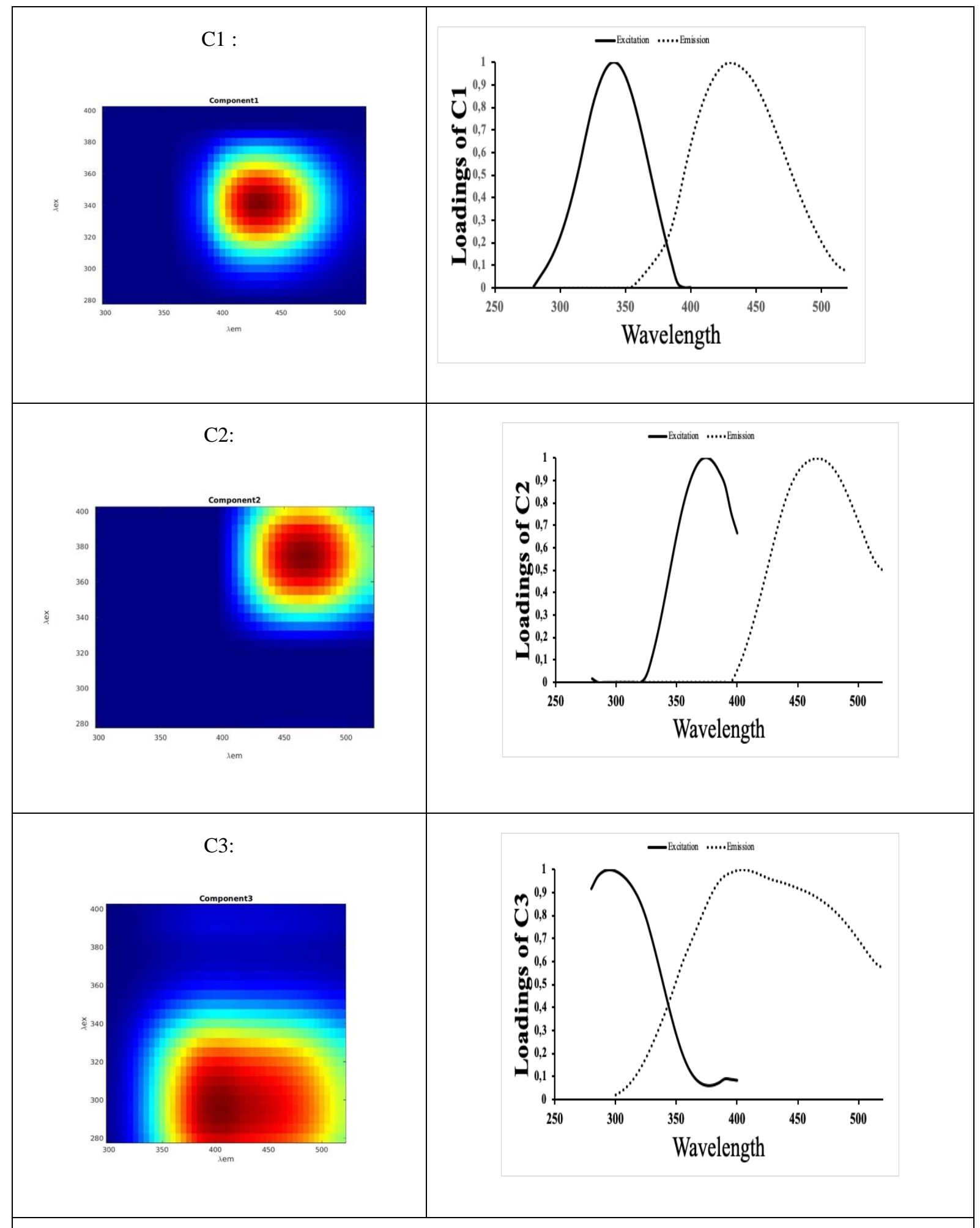

Fig. 9 


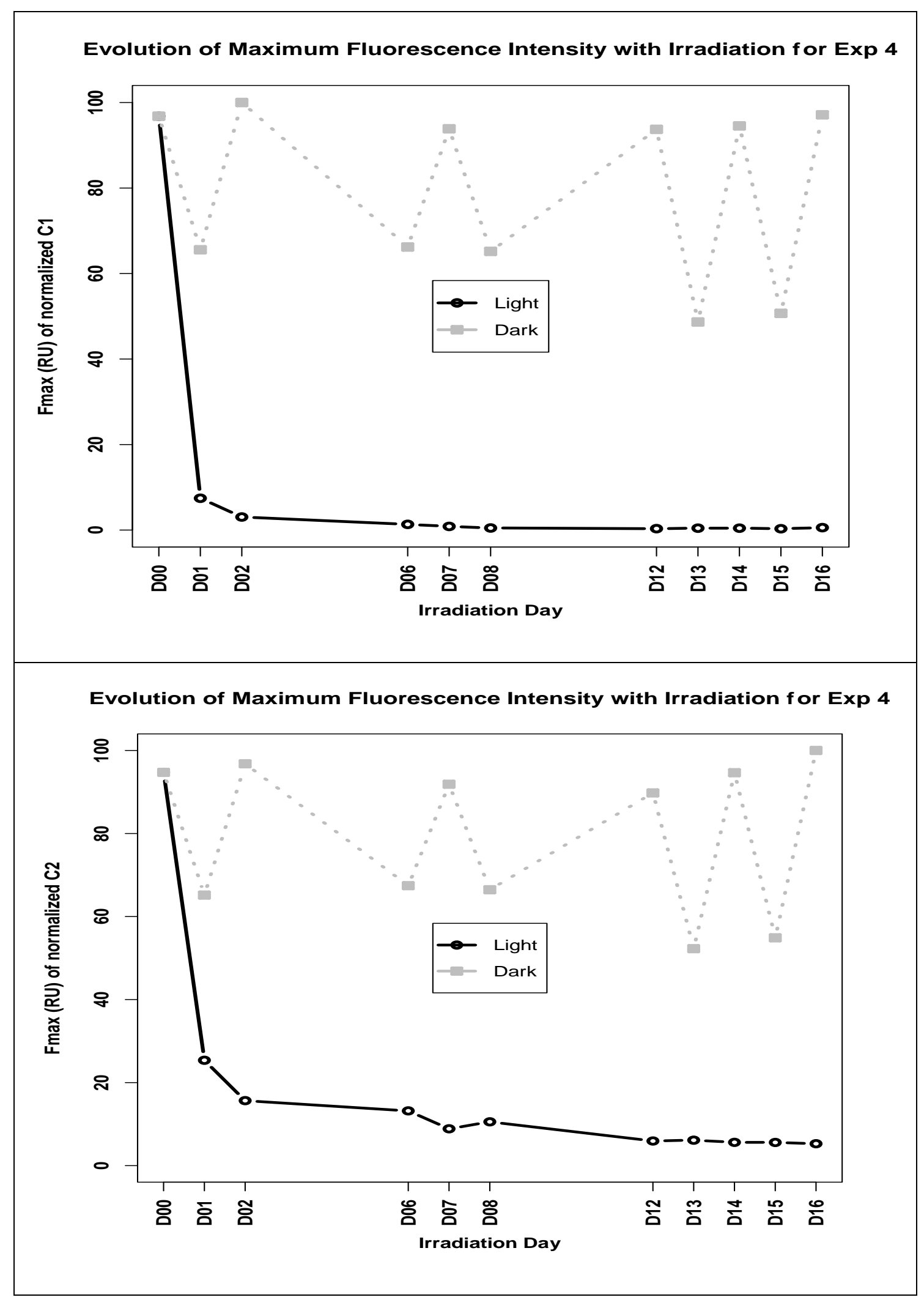




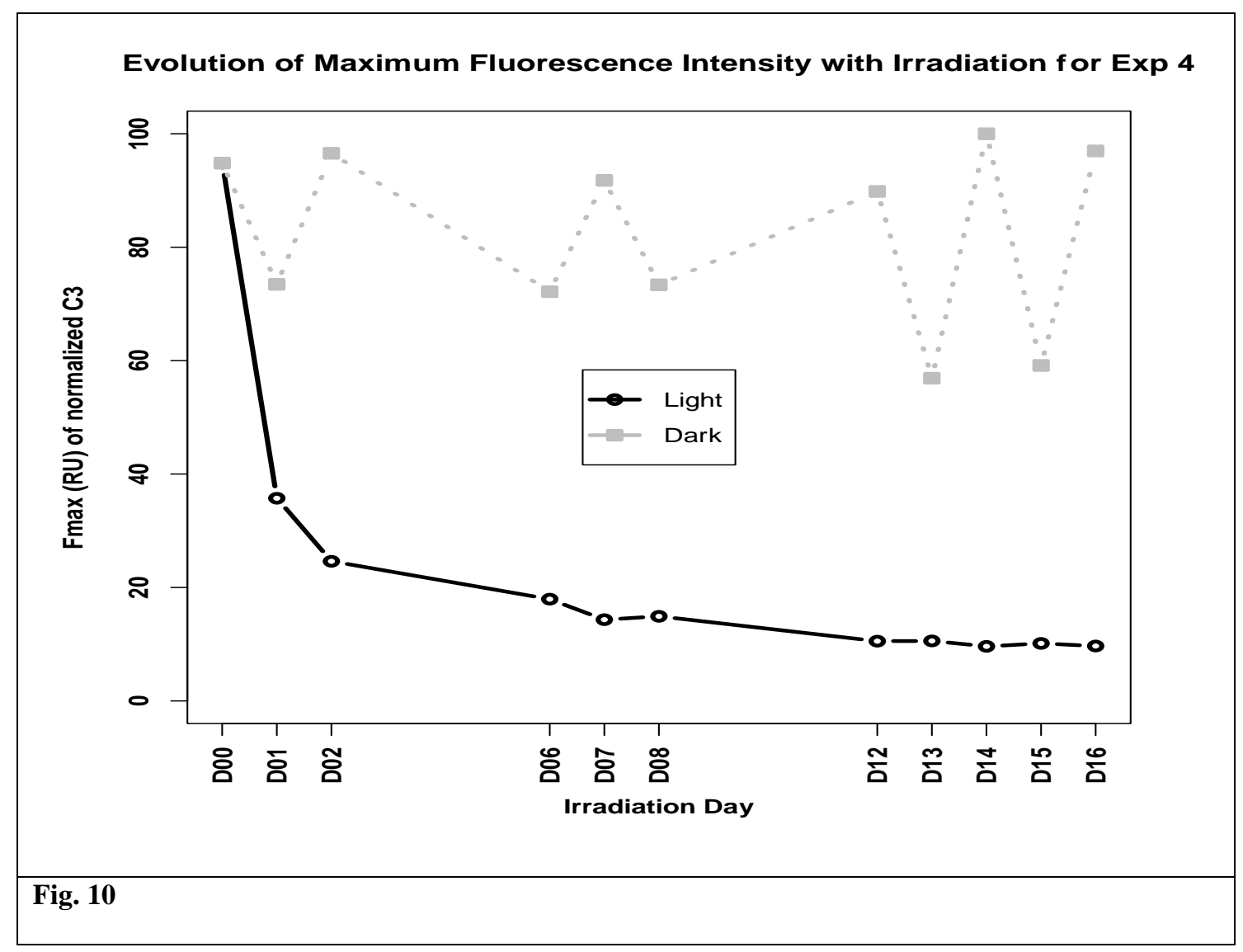

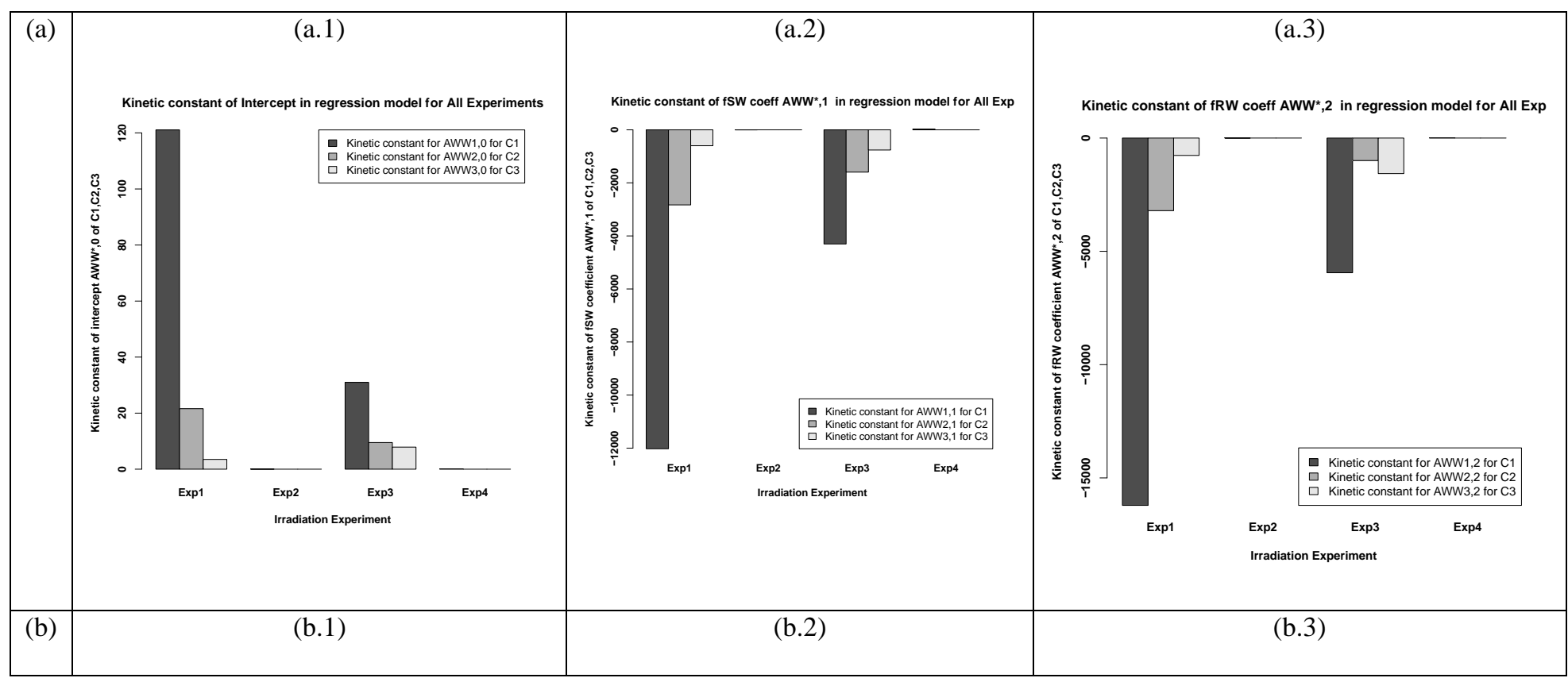




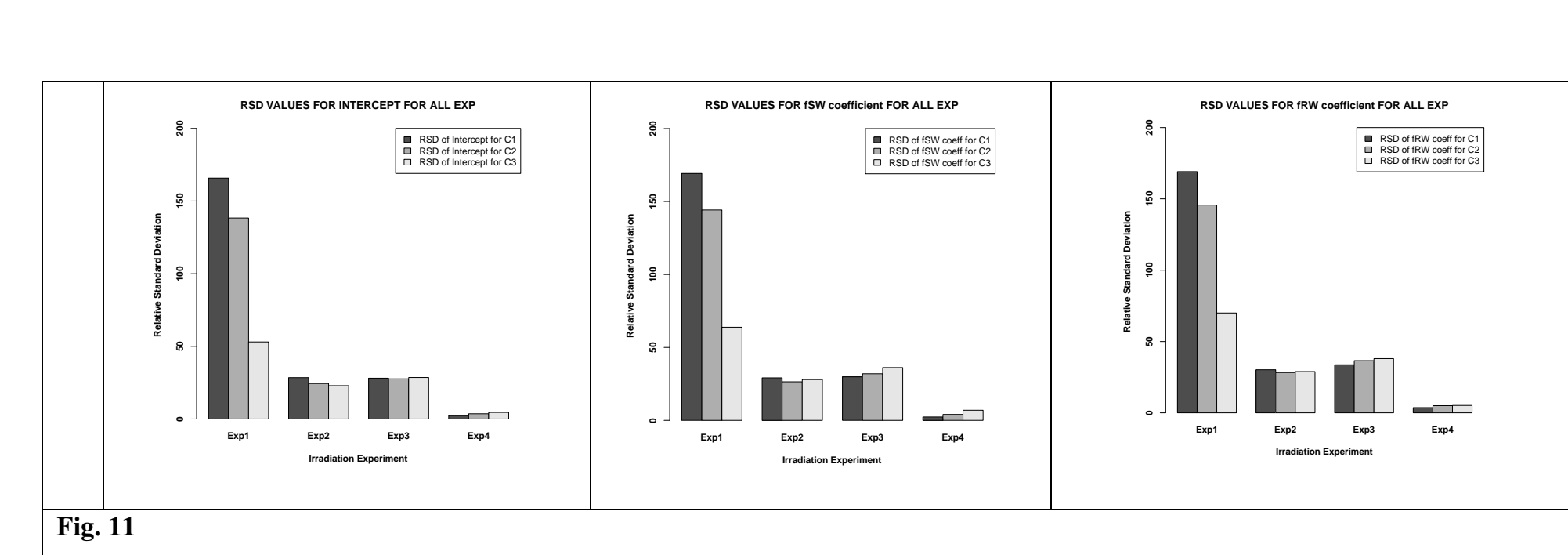


Table 1

Exact volume in each quartz vial (indicated in its corresponding number) is the vertical sum in $\mathrm{mL}$

\section{Sample Number}

\begin{tabular}{lccccccccccccccc}
\hline Water type & $\mathbf{1}$ & $\mathbf{2}$ & $\mathbf{3}$ & $\mathbf{4}$ & $\mathbf{5}$ & $\mathbf{6}$ & $\mathbf{7}$ & $\mathbf{8}$ & $\mathbf{9}$ & $\mathbf{1 0}$ & $\mathbf{1 1}$ & $\mathbf{1 2}$ & $\mathbf{1 3}$ & $\mathbf{1 4}$ & $\mathbf{1 5}$ \\
$\mathbf{R W}$ & 50 & 0 & 0 & 37.5 & 25 & 12.5 & 37.5 & 25 & 12.5 & 0 & 0 & 0 & 25 & 12.5 & 12.5 \\
& & & & & & & & & & & & & & &
\end{tabular}

Table 2

Irradiation Experiments dates and types.

\begin{tabular}{|c|c|c|c|c|}
\hline Experiment & $\begin{array}{c}\text { Filtration state of } \mathrm{RW}, \mathrm{SW} \\
\text { and } \mathrm{WW}\end{array}$ & $\begin{array}{l}\text { Irradiation } \\
\text { Start Date }\end{array}$ & $\begin{array}{c}\text { Irradiation End } \\
\text { Date }\end{array}$ & Duration \\
\hline Exp. 1 & $\mathrm{RW}(\mathrm{F}), \mathrm{SW}(\mathrm{F}), \mathrm{WW}(\mathrm{NF})$ & $10 / 11 / 2015$ & $26 / 11 / 2015$ & 16 days \\
\hline Exp. 2 & RW(NF), SW(F), WW(F) & $02 / 12 / 2015$ & $17 / 12 / 2015$ & 16 days \\
\hline Exp. 3 & RW(F), SW(NF), WW(F) & $15 / 02 / 2016$ & $01 / 03 / 2016$ & 16 days \\
\hline Exp. 4 & $\mathrm{RW}(\mathrm{NF}), \mathrm{SW}(\mathrm{NF}), \mathrm{WW}(\mathrm{NF})$ & $11 / 05 / 2016$ & $27 / 05 / 2016$ & 16 days \\
\hline
\end{tabular}

F indicates filtered state and NF means Not Filtered state 


\section{Table 3}

Correspondence of PARAFAC components in this study with components reported elsewhere in literature.

\begin{tabular}{|c|c|c|c|c|}
\hline \multicolumn{3}{|c|}{ The present study } & \multirow{2}{*}{$\begin{array}{l}\text { Correspondence } \\
\text { with literature }\end{array}$} & Correspondence with openfluor.org \\
\hline Component & $\begin{array}{l}\text { Ex/Em } \\
(\mathrm{nm})\end{array}$ & Characterization & & \\
\hline $\mathrm{C} 1$ & $340 / 430$ & $\begin{array}{l}\text { Wastewater/nutrient } \\
\text { enrichment tracer; } \\
\text { terrestrial humic- } \\
\text { like }\end{array}$ & $\begin{array}{l}\text { G3(1), Peak C } \\
(2), C 4(3) ;\end{array}$ & $\begin{array}{l}\text { RecycleG7 C3; RecycleStM C1; } \\
\text { RecycleWTP C3; RecycleWRAMS C4; } \\
\text { RecycleRH C1; RecyclePC C3; } \\
\text { Peleato_OzoneAOP_biofilter C1; } \\
\text { MIEX-DOC-GOLD C2; Vines_WWEff } \\
\text { C1; Fuirosos_Drought C2 }\end{array}$ \\
\hline $\mathrm{C} 2$ & $375 / 465$ & $\begin{array}{l}\text { More humificated or } \\
\text { ligneous } \\
\text { compounds }\end{array}$ & $\begin{array}{l}\text { Peak A (2); } C_{450} \\
(4) ; C 2(7)\end{array}$ & $\begin{array}{l}\text { osPARAFAC_RioNegro } \\
\text { Masanbay_Korea C2; Partners } \\
\text { MIEX-DOC-GOLD C4; Drink }\end{array}$ \\
\hline C3 & $295 / 405$ & $\begin{array}{l}\text { Anthropogenic } \\
\text { humic materials, } \\
\text { agricultural; } \\
\text { Microbial } \\
\text { component }\end{array}$ & $\begin{array}{l}\text { Peak M(2); } \\
\text { C2(5);C5(6); } \\
\text { C2(8) }\end{array}$ & $\begin{array}{l}\text { FloridaKeys C1; Shutova_F C1; } \\
\text { WAIS_Holocene_3 } \\
\text { NeusePOMDOM C2; Kauai C1; } \\
\text { Vines_BWR C1; Fuirosos_Drought C1; } \\
\text { Vines_WWEff } \\
\text { Shakil_Peel2015t2017_5comp C2; } \\
\text { RaskaDOM C1; Arctic Seawater C2; } \\
\text { Borisover_wastewater treatment plants } \\
\text { C2; } \\
\text { BengalBasin_GW_Nadia_Acidification } \\
\text { C1 }\end{array}$ \\
\hline
\end{tabular}

\footnotetext{
1. Murphy et al. (2011); 2. Coble (1996) ; 3. Lapierre and del Giorgio (2014); 4.Wünsch et al. (2017); 5.Murphy et al. (2008); 6.Stedmon and Markager (2005);7. Abaker et al. (2018); 8. Cohen et al., 2014
} 


\section{Table 4}

Values of Multilinear regression parameters of PARAFAC components and $f_{S W}$ and $f_{R W}$ before irradiation which are initial conditions for the second order model

\begin{tabular}{|c|c|c|c|c|c|c|c|c|c|c|c|c|}
\hline & \multicolumn{4}{|c|}{ Coefficients of $\mathrm{C} 1$} & \multicolumn{4}{|c|}{ Coefficients of $\mathrm{C} 2$} & \multicolumn{4}{|c|}{ Coefficients of $\mathrm{C3}$} \\
\hline Exp. & $\begin{array}{l}\mathrm{A}^{\mathrm{WW}} \mathrm{w}_{0,0} \\
\text { interce } \\
\text { pt }\end{array}$ & $\begin{array}{l}\mathrm{A}^{\mathrm{WW}} \mathrm{w}_{1} \\
, 1 \\
\left(\mathbf{f}_{\mathrm{Sw}}\right)\end{array}$ & $\begin{array}{l}\mathrm{A}^{\mathrm{WW}} \mathrm{w}_{1} \\
, 2 \\
\left(\mathbf{f}_{\mathrm{RW}}\right)\end{array}$ & $\mathbf{r}^{2}$ & $\begin{array}{l}\mathrm{A}^{\mathrm{Ww}, 0} \\
\text { interce } \\
\text { pt }\end{array}$ & $\begin{array}{l}\mathrm{A}^{\mathrm{WW}}, \\
1 \\
\left(\mathbf{f}_{\mathrm{SW}}\right)\end{array}$ & $\begin{array}{l}\mathrm{A}^{\mathrm{WW}}, \\
2 \\
\left(\mathbf{f}_{\mathrm{RW}}\right)\end{array}$ & $\mathbf{r}^{2}$ & $\begin{array}{l}\mathrm{A}^{\mathrm{WW}} \mathrm{w}_{\mathbf{0}} \\
\text { interce } \\
\text { pt }\end{array}$ & $\begin{array}{l}\mathrm{A}^{\mathrm{WW}}, \\
1 \\
\left(\mathrm{f}_{\mathrm{SW}}\right)\end{array}$ & $\begin{array}{l}\mathrm{A}^{\mathrm{WW}}, \\
2 \\
\left(\mathbf{f}_{\mathrm{RW}}\right)\end{array}$ & $\mathbf{r}^{2}$ \\
\hline Exp.1 & 8,17 & $-0,08$ & $-0,08$ & 0,99 & 11,86 & $-0,11$ & $-0,10$ & 0,99 & 28,31 & $-0,24$ & $-0,21$ & 0,99 \\
\hline Exp.2 & 62,36 & $-0,61$ & $-0,53$ & 0,99 & 71,53 & $-0,63$ & $-0,54$ & 0,98 & 63,44 & $-0,47$ & $-0,43$ & 0,98 \\
\hline Exp.3 & 61,75 & $-0,62$ & $-0,56$ & 0,98 & 63,89 & $-0,61$ & $-0,55$ & 0,98 & 55,68 & $-0,49$ & $-0,45$ & 0,98 \\
\hline Exp.4 & 94,56 & $-0,94$ & $-0,90$ & 0,99 & 93,17 & $-0,89$ & $-0,83$ & 0,99 & 99,49 & $-0,93$ & $-0,86$ & 0,99 \\
\hline
\end{tabular}

Table 5

Kinetic order of coefficients of multilinear regression for each CP/PARAFAC .

\begin{tabular}{|c|c|c|c|c|c|c|c|c|c|}
\hline & \multicolumn{3}{|c|}{ C1 } & \multicolumn{3}{|c|}{ C2 } & \multicolumn{3}{|c|}{ C3 } \\
\hline & $\mathrm{A}^{\mathrm{WW}}{ }_{1,0}$ & $\begin{array}{l}\mathrm{A}^{\mathrm{WW}}{ }_{1,1} \\
\left(\mathrm{f}_{\mathrm{SW}}\right)\end{array}$ & $\begin{array}{l}\mathrm{A}_{1,2}^{\mathrm{WW}} \\
\left(\mathrm{f}_{\mathrm{RW}}\right)\end{array}$ & $\mathrm{A}^{\mathrm{Ww}_{2,0}}$ & $\begin{array}{l}\mathrm{A}^{\mathrm{Ww}_{2,1}} \\
\left(\mathrm{f}_{\mathrm{SW}}\right)\end{array}$ & $\begin{array}{l}\mathrm{A}^{\mathrm{WW}_{2,2}} \\
\left(\mathrm{f}_{\mathrm{RW}}\right)\end{array}$ & $\mathrm{A}^{\mathrm{WW}_{3,0}}$ & $\begin{array}{l}\mathrm{A}_{3,1}^{\mathrm{wW}_{3,1}} \\
\left(\mathrm{f}_{\mathrm{SW}}\right)\end{array}$ & $\begin{array}{l}\mathrm{A}^{\mathrm{Ww}}{ }_{3,2} \\
\left(\mathrm{f}_{\mathrm{RW}}\right)\end{array}$ \\
\hline Exp.1 & 2 & 2 & 2 & 2 & 2 & 2 & 2 & 2 & 2 \\
\hline Exp.2 & 2 & 2 & 2 & 2 & 2 & 2 & 2 & 2 & 2 \\
\hline Exp.3 & 2 & 2 & 2 & 2 & 2 & 2 & 2 & 2 & 2 \\
\hline Exp.4 & 2 & 2 & 2 & 2 & 2 & 2 & 2 & 2 & 2 \\
\hline
\end{tabular}

